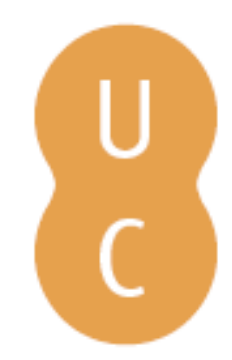

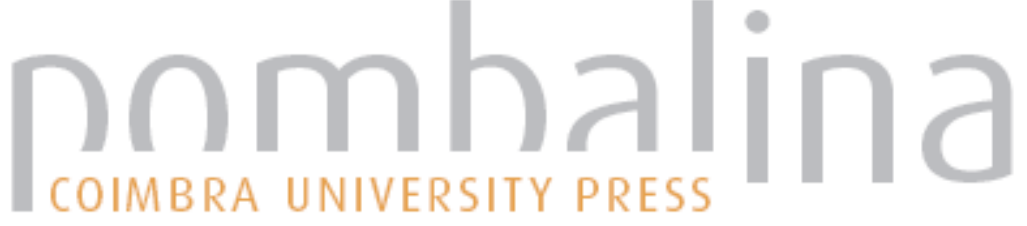

\section{Obras morais: da educação das crianças}
Autor(es):
Plutarco
Publicado por: Centro de Estudos Clássicos e Humanísticos
URL
persistente:
URI:http://hdl.handle.net/10316.2/2417
DOI:
DOI:http://dx.doi.org/10.14195/978-989-721-064-8

Accessed : $\quad$ 26-Apr-2023 10:58:08

A navegação consulta e descarregamento dos títulos inseridos nas Bibliotecas Digitais UC Digitalis, UC Pombalina e UC Impactum, pressupõem a aceitação plena e sem reservas dos Termos e Condições de Uso destas Bibliotecas Digitais, disponíveis em https://digitalis.uc.pt/pt-pt/termos.

Conforme exposto nos referidos Termos e Condições de Uso, o descarregamento de títulos de acesso restrito requer uma licença válida de autorização devendo o utilizador aceder ao(s) documento(s) a partir de um endereço de IP da instituição detentora da supramencionada licença.

Ao utilizador é apenas permitido o descarregamento para uso pessoal, pelo que o emprego do(s) título(s) descarregado(s) para outro fim, designadamente comercial, carece de autorização do respetivo autor ou editor da obra.

Na medida em que todas as obras da UC Digitalis se encontram protegidas pelo Código do Direito de Autor e Direitos Conexos e demais legislação aplicável, toda a cópia, parcial ou total, deste documento, nos casos em que é legalmente admitida, deverá conter ou fazer-se acompanhar por este aviso.

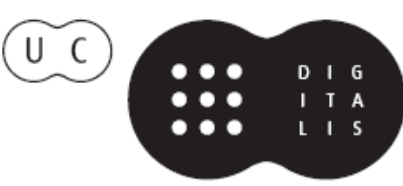




\section{Plutarco}

\section{Obras Morais}

\section{Da Educação das Crianças}

TRADUÇÃo DO GREGO, INTRODUÇÃO E NOTAS JoAqUim PinheIro 
Série "Autores Gregos e Latinos -

TRADUÇÃO, INTRODUÇÁO E COMENTÁRIO”

ISSN: 2183-220X

Apresentação: Esta série procura apresentar em língua portuguesa obras de autores gregos, latinos e neolatinos, em tradução feita diretamente a partir da língua original. Além da tradução, todos os volumes são também caraterizados por conterem estudos introdutórios, bibliografia crítica e notas. Reforça-se, assim, a originalidade científica e o alcance da série, cumprindo o duplo objetivo de tornar acessíveis textos clássicos, medievais e renascentistas a leitores que náo dominam as línguas antigas em que foram escritos. Também do ponto de vista da reflexão académica, a coleçáo se reveste no panorama lusófono de particular importância, pois proporciona contributos originais numa área de investigaçáo científica fundamental no universo geral do conhecimento e divulgaçáo do património literário da Humanidade. 
(Página deixada propositadamente em branco) 
Volume integrado no projecto

Plutarco e os fundamentos da identidade europeia

e financiado pela Fundação para a Ciência e a Tecnologia.

Investigador responsável pelo projecto: Delfim Ferreira Leão. 


\section{Plutarco}

\section{Obras Morais \\ Da Educação das Crianças}

TraduÇÃo do Grego, INTROdUÇÃo E NOTAS DE

Joaquim Pinheiro

Universidade da Madeira

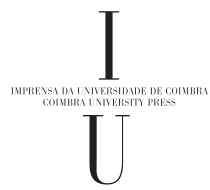




\begin{abstract}
Autor: Plutarco
Título: Da Educação das Crianças

TraduÇão do GREgo, INTROdUÇÃo E NOTAS: JoAquim

Pinheiro Editor: Centro de Estudos Clássicos E

Humanísticos e Imprensa da Universidade de Coimbra

EDIÇÃo: 1a/2008

Concepção Gráfica: Rodolfo Lopes

OBRa REALIZADa No ÂMBITO DAS ACTIVIDADES DA UI\&D

Centro de Estudos Clássicos e Humanísticos

$$
\begin{gathered}
\text { Universidade de Coimbra } \\
\text { Faculdade de Letras } \\
\text { Tel.: } 239859981 \text { | Fax: } 239836733 \\
\text { 3000-447 Coimbra }
\end{gathered}
$$

ISBN: 978-989-8281-07-4

ISBN Digital: 978-989-721-064-8

DOI: http://dx.doi.org/10.14195/978-989-721-064-8

Depósito Legal: 285 068/08
\end{abstract}

Obra Publicada com o Apoio de:

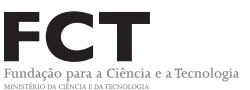

\title{
SoPlutarco
}

Sociedade Portuguesa de Plutarco

POCI $/ 2010$ 


\section{ÍNDICE}

INTRODUÇÃO

i. Autoria do Texto

2. Conteúdo do Tratado

DA EDUCAÇÃO DAS CRIANÇAS

Bibliografia 


\section{INTRODUÇÃO}




\section{INTRODUÇÃO ${ }^{1}$}

\section{Autoria do teXto}

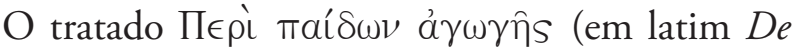
liberis educandis, que traduzimos por Da educação das crianças) foi escrito, muito provavelmente, nos séculos I ou II d. C. É o único tratado da Antiguidade, especificamente dedicado à pedagogia, que nos chegou na íntegra, facto que lhe confere o direito de ser um documento indispensável para qualquer estudo de história da educação no Ocidente. Por valorizar os benefícios da paideia, este tratado foi lido e traduzido no Humanismo, tendo mesmo merecido uma tradução em separado dos outros tratados das Obras Morais. Além disso, influenciou o pensamento de figuras táo marcantes como Erasmo, Montaigne, Milton, Coménio e Rousseau, entre outros.

Desde o século XVI, por Muretus, humanista francês (Marc Antoine Muret) ${ }^{2}$, que se pôs em causa a sua autoria, mas somente D. Wyttenbach (1820) de-

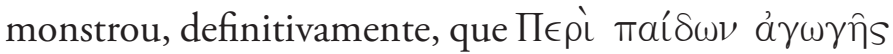
não é um escrito juvenil de Plutarco, argumentando com elementos estilísticos, vocabulares e temáticos, que

${ }^{1}$ A introdução retoma alguns dos elementos que desenvolvemos em trabalhos anteriores: J. Pinheiro (2003: 473-484) e (2007: 349-362). Expressamos, ainda, o nosso agradecimento ao Doutor Delfim F. Leâo pelos seus diversos contributos na fase final de preparação deste trabalho.

${ }^{2}$ Variae lectiones 14.1: (...) in libello, qui Plutarchi quidem non videtur, sed inter ipsius opuscula tamen legitur, de liberis educandis ... (no pequeno livro Da educação das crianças, que não parece ser de Plutarco, mas que todavia se lê entre os seus opúsculos...). 
são aceites, em geral, pela crítica actual, como é o caso de B. Weissenberger (1994: 64-76), que sintetiza as peculiaridades linguísticas do tratado, a maior parte já referidas no estudo de D. Wyttenbach (1820), ficando, dessa forma, demonstradas as suas diferenças em relação ao restante corpus plutarquiano. Enunciemos, então, os principais elementos que indicam não ser este tratado da autoria de Plutarco:

a) à semelhança dos textos de Plutarco contém um conjunto vasto de citaçôes e alusôes, mas elas parecem ser encaixadas no texto de forma pouco natural;

b) não faz referência a Píndaro e a Menandro, dois dos autores mais citados nas Obras Morais;

c) usa mais a conjunção final ìva do que is e

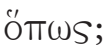

d) utiliza com frequência a primeira pessoa do singular (1A, 4E, 5C, 6B e E, 7A e B, 8E, 10B, D e E, 11A, C e D, 12A e F, 13C, 14A), ao contrário do que acontece nos restantes tratados, em que Plutarco usa, geralmente, a primeira pessoa do plural ou a forma impessoal.

Para B. Weissenberger (1994), o tratado Da educação das crianças seria um gymnasma de um dos alunos de Plutarco (14 C); outros estudiosos, porém, consideram verosímil alguém o ter escrito a partir de notas do próprio Plutarco. É certo que o autor deste tratado beneficiou durante muitos séculos da identificação com Plutarco, até porque a maioria das ediçóes das Obras Morais apresenta como primeiro texto o 
tratado Da educação das crianças, conforme o Catálogo de Lâmprias. No Corpus de Planudes, no entanto, ocupa a segunda posição, após o tratado $D a$ virtude e do vício.

\section{Conteúdo do Tratado}

Tudo o que Platão nos diz de Protágoras refere-se à possibilidade da educação. Mas não é só dos pressupostos do estado e da sociedade e do common sense político que para os sofistas deriva a sua solução; ela se estendia a conexóes muito mais amplas. O problema da possibilidade de educar a natureza humana é um caso particular das relaçóes entre a natureza e a arte em geral. Muito instrutiva para este aspecto do problema é a contribuição de Plutarco no seu livro A Educação da Juventude, que tão fundamental seria para o Renascimento, em que as suas ediçóes se repetiram e as suas ideias foram decisivas para a nova pedagogia. $O$ autor declara na introdução que conhece e utiliza a literatura antiga referente à educação [Lib. ed. 2A], o que já teríamos notado, mesmo sem ele ter dito. Isto náo se refere a este tema concreto, mas também ao capitulo seguinte, em que trata dos três factores fundamentais de toda a educação humana: natureza, ensino e hábito. É evidente que tudo isto se baseia em teorias pedagógicas mais antigas. W. Jaeger ( ${ }^{4} 2001$ : 363)

Embora não apresente uma posição pedagógica inovadora, uma vez que podemos identificar as influências de Platão ${ }^{3}$ e Xenofonte ${ }^{4}$ ou das concepçóes

${ }^{3}$ A. E. Velázquez Fernández (1999: 501-514).

${ }^{4}$ E. Berry (1958: 390 e sqq.) demonstra, claramente, que várias ideias deste tratado podem ser encontradas na obra de Xenofonte. 
pitagóricas, aristotélicas e estóicas, estamos na presença de um tratado ecléctico, que propóe uma educação que náo se distancia da prática adoptada durante a época em que Plutarco viveu. Além disso, não encontraremos no tratado explanaçóes sobre as competências científicas dos educandos, uma vez que interessou ao seu autor demonstrar, acima de tudo, que a formação educativa quer no seio familiar, quer junto do paidagogos e do didaskalos ${ }^{5}$ contribui decisivamente para moldar o carácter e para obter a arete.

O tratado tem, em geral, uma clara vocação didáctica e ética que se percebe na exploração de tópicos como: a arete (2A), a dikaiopragia (2A), a kalokagathia (4B) ou por meio da relaçáo entre arete e eudaimonia (5C). Além disso, analisa o percurso educativo da criança, em que os diversos momentos se adaptam aos padrôes de crescimento, em concomitância com uma disposição cronológica: o nascimento, os primeiros anos, a infância, a juventude e o casamento. A propósito da educação e do crescimento, considera J. Bruner (1999: 17) que: "A educação é, no fim de contas, um esforço para auxiliar ou moldar o crescimento. Ao conceber uma educação para os jovens, seria de uma grande imprudência ignorar o que se sabe acerca do crescimento, das suas restriçóes e oportunidades. E uma teoria da educação (...) é com efeito uma teoria do modo como

${ }^{5}$ T. Morgan (2000r: 17) define paidagogos e didaskalos da seguinte forma: 'Paidagogos tends to mean 'attendant' rather than 'schoolteacher', though paidagogoi did have an educational role in a broad sense. Didaskalos has an enormously wide range of meaning which can include any aspect of literate education". 
o crescimento e o desenvolvimento são auxiliados por diversos meios." Apesar de no tratado Da educação das crianças não existir a preocupação de diferenciar comportamentos psicossomáticos, é, contudo, inegável a concepção gradativa do acto educativo. Está subjacente que a paideia pode contribuir para o bem-estar do indivíduo, estando a noção de paideia muito associada ou dependente dos vocábulos que na língua grega traduzem equilíbrio e moderação: eutaxia e sophrosyne (8C), eukosmia e sophrosyne (11C), eutaxia e kosmiotes (12A) e sophronismos (14B).

Outro elemento a realçar é a diferenciação de dois tipos de educação que podem e devem coexistir: a educação feita no âmbito familiar ${ }^{6}$ e a educação desenvolvida junto de mestres. Logo no incipit, o autor sintetiza a intenção de abordar a educação das crianças $\left(\right.$ agoge $^{7}$ ) e de aconselhar os pais no sentido de 59-71).

${ }^{6}$ Sobre o papel da família na educaçáo, vide F. Albini (1997:

${ }^{7} \mathrm{O}$ vocábulo agoge, cujo sentido etimológico se relaciona com "a acção de conduzir ou transportar", significa também "maneira de tratar uma questấo, método, conduta" e "educação", por conseguinte, sugere mais do que um sistema organizado, um processo de acompanhamento e formaçáo moral da criança, noção que irremediavelmente se perde na traduçấo. Por agoge, define-se, em geral, o sistema educacional de Esparta, embora neste tratado essa relação não seja claramente estabelecida. N. Kennel (1995: 5) escreveu o seguinte sobre a agoge: "in the eyes of writers such as Xenophon, Plato, and their many successors over the centuries - philosophers, sophists, historians, and biographers - the agoge's harsh discipline transformed boys into soldiers who were the embodiments of courage, virtue, and obedience". Recorrendo sobretudo a textos epigráficos, N. Kennel demonstra que a agoge sofreu diversas alteraçóes desde a Época Clássica até ao momento em que Roma passou a dominar a Grécia, defendendo que a agoge era mais do que um 
proporcionarem uma formação moral aos seus filhos. Sublinhe-se, ainda, que as primeiras palavras do tratado indiciam a alteração que se operou na passagem da Época Clássica para a Época Helenística: enquanto na Época Clássica cabia à polis, a esse colectivo mais ou menos abstracto, a função educativa, como se lê, por exemplo, nas palavras de Simónides: "A cidade é mestra do homem” (frg. 90 West), na Época Helenística, por sua vez, a família passa a ser considerada o centro vital da formação. Além disso, percebe-se ao longo do tratado que a acção educacional da família não se esgota nos primeiros anos de vida da criança, uma vez que depois é vital, por exemplo, escolher um pedagogo competente e bem formado, além da necessidade de se acompanharem regularmente as liçóes dos filhos (9C-D), uma vez que, segundo o autor do tratado, só os pais que se comprometem com a educação dos seus filhos têm autoridade moral para os corrigir.

Por isso, antes de se deter nas questóes directamente relacionadas com a pedagogia, o autor discorre sobre os cuidados a ter na procriação dos filhos, como a escolha de mulheres de boa estirpe e nunca heteras nem concubinas ou como é essencial a abstinência de bebidas alcoólicas, pois acredita na transmissão genética ${ }^{8}$. Para

conjunto de ancestrais costumes, pois contribui para a sociedade espartana se distinguir na Hélade.

${ }^{8}$ Nas Obras Morais encontramos vários elementos sobre os traços do carácter fruto de herança familiar: a criança semelhante aos pais (Como distinguir o adulador do amigo 63E); a possibilidade de um bom homem nascer de um mau homem (As delongas da justiça divina 563A) ou de um bom filho nascer de um mau pai (Como deve o jovem ouvir poesia 28C-D); vide F. Albini (1997: 60-1). 
apoiar a sua tese, o autor do tratado recorre a Eurípides (Hércules Furioso 1261-2):

Quando o alicerce de uma família não é fundado com rectidáo, o destino será desgraçado para a descendência.

Para se esclarecer o percurso necessário à formação de um homem recto e modelar, o tratado recorre, com uma argumentação pouco rigorosa, à doutrina dos três elementos (physis, logos e ethos), tão divulgada pelo movimento sofístico e que teve presença muito significativa tanto no pensamento platónico como no aristotélico'. Com respostas diferentes ao longo da história da cultura grega, a questão que esta tríade educacional coloca é, em resumo, a seguinte: sabendo-se que todo o homem tem qualidades inatas, a sua instrução compensará o esforço? O tratado Da educação das crianças responde (2A-B), sem dúvida, de forma afirmativa ${ }^{10}$, ao defender a conciliação e a interdependência dos três elementos (physis, logos e ethos) e valorizando a primazia da instrução em detrimento daquilo que é inato quando se afirma: "a natureza sem instrução é cega, tal como a instrução separada da natureza é insuficiente e o exercício separado de ambos não obtém resultado" (4B). Deste modo, a aquisição de conhecimentos possui um papel fundamental, pois assume-se a necessidade da formação

${ }^{9}$ Cf. e.g. Platão, Ménon 70a, Fedro 269a, Protágoras 323a; Aristóteles, Política 1332a, Ética a Nicómaco 1179b; Xenofonte, Memoráveis 3.9.2, 2.6.39, 3.3.11.

${ }^{10}$ A mesma resposta é dada por Plutarco no tratado Pode a virtude ensinar-se? 
do homem, sendo esta um processo exigente e que se baseia no exercício (askesis). Como acontece diversas vezes ao longo do texto, a agricultura surge como termo de comparação, pois tanto o homem como a terra precisam de ser cultivados para dar fruto (e.g., $2 \mathrm{~B}$ e $4 \mathrm{C})^{11}$.

Como é norma num tratado deste teor, proliferam os argumentos, mediante anedotas, provérbios, figuras literárias, alusôes e citaçôes. São citados variados autores: Eurípides (1B, 1C, 6B, 10A, 11E), Platão (3F, 8C, 11E), Hesíodo (9E), Focílides (3F), Sótades (11A), Demóstenes (6D), Xenofonte (8D), Demócrito (9F) e um epigrama de Eurídice no fim do tratado. Nesta lista, por comparação com as Vidas Paralelas e as Obras Morais de Plutarco, notam-se as ausências, por exemplo, de Píndaro e de Menandro, dois dos autores mais citados. No que diz respeito a pequenas histórias, muitas delas anedóticas, também se podem encontrar em quase todas as secçóes do tratado: Diofanto (1C), Arquedamo (1D), Diógenes (2A e 5C), um tessálio não identificado (2F), Licurgo (3A), Sócrates (4D, 6A, 10C), Aristipo (4F), Estílpon (5F), Péricles e Demóstenes (6C-D), Apeles (6F), Bíon (7C), Gilipo (10B), Arquitas e Platão (10D), Sótades e Ptolomeu Filadelfo (11A), Teócrito de Quios (11A-B) e Eurídice (14B-C). Essas histórias visam, em alguns casos, ilustrar o processo educativo, como acontece naquela em que são protagonistas o legislador espartano Licurgo e dois cães (3A-B), e que tem por objectivo demonstrar como mais determinante do

${ }^{11}$ A imagem da agricultura associada à educação é muito habitual na literatura grega; vide e.g. Platão, Fedro 276b ou Plutarco, Vida de Coriolano 1.2-4. 
que a eugenia é a paideia. É, então, na qualidade formativa e no acompanhamento atento e interventivo que os pais devem investir o seu tempo, em especial nos primeiros anos de vida das crianças (3E). O autor do tratado considera, deste modo, a infância o momento mais oportuno para se lançarem as bases dos verdadeiros valores e costumes, e, ao mesmo tempo, apela à responsabilidade e zelo dos pais. Ao citar o provérbio "quem vive perto de um coxo, aprende a coxear" (4A), adverte para o cuidado a ter na escolha dos jovens escravos, os paidagogoi, pois teráo de ter um carácter virtuoso e de saber pronunciar a língua grega com fluência e correcção. Caberá a estes paidagogoi a educação da criança, logo que atinja os sete anos. Não se pense, porém, que os pais ficam dispensados do processo formativo, pois este tratado confere aos pais deveres inalienáveis e critica aqueles que os ignoram (4A-E).

Além disso, é crucial a escolha de um paidagogos diligente, recto, experiente e capacitado para incutir os melhores valores nas crianças. Nesse sentido, mais uma vez se estabelece a analogia entre educação e agricultura, transformando a primeira num investimento frutuoso. Como se pode inferir, o programa educativo proposto pelo tratado não tem uma justificação filosófica para a paideia, atribuindo-lhe, recorrentemente, um carácter moral, de tal forma que se gera alguma confusão entre virtude e educação. A insistência nas vantagens da educação, que surgem no texto de forma um pouco desordenada, a enumeração das qualidades do bom preceptor e a necessidade de bem pagar essa função levam-nos a pensar 
que o autor do tratado estaria ligado a essa actividade.

Da análise destes textos, não podemos deixar de notar que os vocábulos agoge e paideia têm significados próximos que só o contexto ajuda a discernir. Em 5C, voltam a fazer parte do mesmo sintagma. Atente-se no texto:

Em resumo, eu afirmo [...] que no princípio, no meio e no fim existe algo de fundamental: uma conduta (agoge) séria e uma educação (paideia) obediente às leis, pois defendo que todas estas coisas favorecem e auxiliam a obtenção da virtude e da felicidade.

Este texto considera, assim, a agoge e a paideia uma necessidade para a conquista da virtude e da felicidade. Enquanto a beleza, a saúde, a força são qualidades passageiras, a paideia é perene, uma vez que, como se pode ler no texto (5E), a educação é o único dos bens que temos que é imortal e divino. Recorde-se que, de acordo com a concepção platónica, a paideia tem como finalidade potencializar todas as capacidades humanas.

De seguida, não podemos de deixar de chamar a atençáo para outro elemento muito importante neste tratado: a referência ao enkyklion paideuma ('cultura geral'). A partir da Época Helenística, em especial, notase a preocupação de criar um projecto para a educação intermédia, entre a acçáo desenvolvida, por um lado, pelo paidagogos, pelo grammatistes (que ensinava a leitura, a escrita, a aritmética e a literatura) e pelo paidotribes e kitharistes (que tinham a seu encargo o ensino do exercício físico e da música; a medicina e retórica, 
por sua vez, eram ensinadas em escolas especializadas) e, por outro lado, pelas escolas superiores (e.g. a escola de filosofia e retórica de Isócrates; a Academia de Platão, com matemática e filosofia; o Liceu de Aristóteles). Para cumprir esse objectivo ampliou-se o plano de estudos, ganhando forma o conceito da enkyklios paideia. H. I. Marrou (1990r: 276) refere a propósito da enkyklios paideia: «Com efeito, nos escritores da Época Helenística e Romana encontram-se numerosas mençôes deste termo, que não caberia transcrever literalmente por "enciclopédia", noção esta bem moderna (a palavra data apenas do século XVI) e que não corresponde, absolutamente, à expressão antiga. "Enciclopédia" evoca, para nós, um saber universal: por mais elásticos que pos-

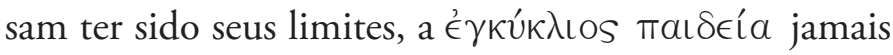
pretendeu abarcar a totalidade do saber humano: na verdade, de acordo com o sentido que reveste normal-

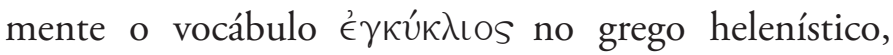

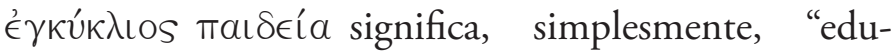
cação vulgar, corrente, comummente transmitida" donde a tradução que propus: "cultura geral". Tal noção sempre apresentou contornos bastante vagos: o uso que dela se faz hesita entre duas concepçóes: ora é a cultura geral que convém ao perfeito cavalheiro, sem referência explícita ao ensino, e que reúne o teor de toda a educação, secundária e superior, escolar e pessoal; ora é a cultura de base, a propedêutica, os тротаı $\delta \in \dot{\mu} \mu \alpha \tau \alpha$, que devem preparar o espírito para receber as formas superiores do ensino e da cultura, ou, numa palavra, o programa ideal do ensino secundário. Esta concepção é, 
em particular, a dos filósofos, seja quando denunciam a inutilidade da $\epsilon^{\prime} \gamma \kappa u ́ k \lambda \iota o s ~ \pi \alpha \iota \delta \in i ́ a$ para a cultura filosófica, como o fazem Epicuro e, com ele, os cínicos e os cépticos de todas as escolas, seja quando insistem em sua necessidade, como convém fazê-lo à maioria das seitas e, notadamente, desde Crisipo, aos estóicos». T. Morgan (2000r: 272) defende que, apesar da aceitação aparente e do realce que lhe é concedido por muitos autores, a enkyklios paideia terá sempre competido com outras formas de educaçáo (militar, profissional, etc.). Vejamos, entâo, como o texto (7C) introduz o enkyklion paideuma, um conceito educativo característico da Época Helenística ${ }^{12}$ :

É necessário, pois, que a criança de condiçâo livre não deixe de ouvir e de observar qualquer uma das disciplinas que integram a chamada cultura geral, mas deve aprender estas de passagem, como em relação ao gosto (pois é impossível ser perfeito em tudo), e deve venerar a filosofia.

O texto distingue a enkyklios paideia da filosofia, dando a primazia a esta ${ }^{13}$. Ainda segundo T. Morgan (2000r: 34), neste passo a enkyklios paideia pode entender-se como uma preparação alargada e intensiva

${ }^{12}$ Vide sobre este assunto G. Lachenaud (1997: 65-102).

${ }^{13}$ Entre os autores latinos, Plínio-o-Velho (História Natural 1. 14), por exemplo, recomenda a enkyklios paideia grega como prefácio a outras actividades; por sua vez, Vitrúvio (Sobre a arquitectura 6.4) aconselha-a como prelúdio ao estudo da arquitectura; é, no entanto, Quintiliano (1.10.1) que define as áreas educativas da orbis doctrina: leitura e escrita; gramática; literatura; geometria; astronomia; princípios de música e lógica. Realce-se o facto de Quintiliano excluir a filosofia da orbis doctrina, tal como a retórica. 
que precede outras formas de educação ou exercícios ${ }^{14}$. Note-se que para os membros da Antiga Academia e para os Peripatéticos a enkyklios era uma importante fase preparatória do estudo da filosofia, ao contrário dos Cínicos ou Epicuristas que se concentravam sobretudo nas questôes éticas e dos Cépticos que não deixavam de manifestar as suas reservas sobre as possibilidades de se atingir o conhecimento $^{15}$. Porventura para valorizar a associação da enkyklios à filosofia, o autor introduz, de seguida, o que entende ser o papel da filosofia na formação. Com a afirmação "é necessário que a filosofia encabece a restante educação" (7D), assume-se que pertence à filosofia a primazia na formação, em detrimento da retórica cujo valor é secundarizado ${ }^{16}$. Se a medicina e a ginástica são ciências que se dedicam ao cuidado (epimeleia) do corpo (soma), a filosofia, por sua vez, é o único remédio (pharmakon) para a alma (psyche). Quais os benefícios da filosofia? São diversos e de vária ordem (7D-E):

${ }^{14}$ Relativamente às disciplinas que faziam parte da enkyklios, escreveu H. I. Marrou (1990r: 277) que a "enkyklios paideia procurou absorver a filosofia e também outras disciplinas como a medicina, arquitectura, direito, desenho e arte militar. Porém, a sua base programática continua a ser constituída pelo triuium (gramática, retórica e dialéctica) e pelo quadriuium (geometria, aritmética, astronomia e teoria musical), segundo a divisão tradicional".

${ }^{15}$ Cf. N. Abbot (1980: 162); este estudo refere ainda o facto de os Estóicos se encontrarem por vezes mais próximos da concepção da Antiga Academia (e.g. Crisipo SVF III 378, Posidónio) e em outras mais de acordo com os Cínicos ou os Epicuristas (e.g. Zenão, Politeia: SVF I 129).

${ }^{16}$ Neste aspecto, a educação proposta pelo tratado difere das teorias educacionais romanas que enfatizam o papel da retórica e da oratória; cf. E. Berry (1958: 389). 
Na verdade, graças a ela e com o seu auxílio é possível saber o que é bom e inútil, justo e injusto, em resumo, o que se deve escolher e evitar; como deve ser o relacionamento com os deuses, os pais, os idosos, as leis, os estrangeiros, os magistrados, os amigos, as mulheres, as crianças e os criados. Porque é necessário temer os deuses, honrar os pais, respeitar os idosos, observar as leis, obedecer aos magistrados, amar os amigos, ser sensato com as mulheres, ser terno com as crianças e não maltratar, rudemente, os escravos. E, o mais importante, náo rejubilar, em excesso, na prosperidade, nem ficar muito aflito na desgraça; não se entregar por completo aos prazeres, nem ser precipitado ou furioso na cólera.

De seguida, dando com exemplo Péricles, Arquitas de Tarento, Díon de Siracusa e Epaminondas de Tebas, o tratado advoga a conciliaçáo entre "os dois maiores bens" (8A), o exercício da política e a filosofia.

Até ao final, o autor do tratado continua o encómio da educação, abordando vários temas pertinentes, dos quais realçamos:

a) o uso de livros (8B): aconselha a aquisição e a preservação de obras antigas, pois elas são o instrumento (organon) e é a elas que vamos buscar o conhecimento;

b) a educação física (8C-D): o exercício corporal feito com o apoio do pedótriba é muito importante, uma vez que é bom para a infância e para quando se atingir a velhice; contudo, não se deve exagerar no esforço físico para que os jovens não renunciem ao estudo (mathema) por causa da fadiga;

c) a educação de crianças pobres: ao dar conselhos sobre a educação de crianças de condição livre exclui as 
pobres e pebleias? A educação é só para os ricos? Em $8 \mathrm{E}$, o autor do tratado diz que por causa da tyche as crianças que nasceram em famílias sem recursos não podem tirar proveito dos seus conselhos; apesar disso, devem os pais fazer tudo o que está ao seu alcance para lhes proporcionar a melhor educação possível;

d) o exercício da memória (mneme) (9D-F): por ser útil para a educação e para outras actividades, os pais devem exercitar a memória das crianças, mesmo quando já são dotadas, por natureza, de uma boa memória, até porque, como diz o texto, "a memória dos actos passados é um exemplo de prudência para situaçóes futuras" $(9 \mathrm{~F})$;

e) a pederastia (11C-F): o autor aceita-a desde que os mestres, como Sócrates, Platão, Xenofonte, Ésquines e Cebes, sejam amantes da alma e incutam nos jovens a virtude e o gosto pela participação na vida pública; se, pelo contrário, os mestres apenas manifestam desejo pela beleza, o autor revela-se contra a pederastia.

O objectivo central do tratado Da educação das crianças é, assim, educar ou formar um homem honesto, habilitado intelectualmente, bem integrado na sociedade, capaz de aprofundar e desenvolver as suas faculdades: um pepaideumenos. Acredita-se que os valores e o apoio familiar, por um lado, e a instrução junto dos paidagogoi e didaskaloi, por outro, terão um efeito decisivo na mentalidade, nas atitudes, nas manifestaçóes e no espírito do indivíduo. Como afirma W. Jaeger $\left({ }^{4} 2001: 3\right)$ : "Ela [paideia] é o princípio por meio do qual a comunidade humana conserva e transmite a sua peculiaridade física 
e espiritual". Em suma, pela paideia atingir-se-á a arete e a eudaimonia, quer como realização pessoal, quer num âmbito mais vasto como sejam a família e a sociedade.

Até ao final do tratado, o autor continua o encómio da educaçáo, detendo-se em temas tão pertinentes como: a filosofia, a coroaçáo da educação; a arte da expressão; a educação física, aqui com menos relevo; a pederastia; a utilidade da memória; o casamento como paideia, por corrigir comportamentos.

Por fim, para facilitar a leitura deste breve tratado, deixamos ao leitor a estrutura temática:

1A-2A: introdução; o genos: conselhos para uma boa génese dos filhos;

2A-3B: factores para a eficácia da agoge;

3B-3F: a importância da amamentação no crescimento da criança;

3F-5C: o cuidado na escolha dos paidagogoi e didaskaloi;

5C-6A: a paideia como um bem supremo;

6A-7B: a retórica: a oportunidade do silêncio e a virtude de não falar a despropósito;

7C-8B: o importante papel da filosofia na paideia; os livros;

8B-E: o exercício do corpo não deve superar o do espírito e do intelecto; a educação e a pobreza;

8E-9A: o equilíbrio na aplicação da autoridade, com a justificada alternância de trabalho, punição e louvor;

9A-9F: a supervisão das liçóes pelos pais; incremento de práticas de memorização; 
9F-11C: diversos conselhos morais;

11C-12A: a pederastia;

12A-D: a adolescência e os seus perigos;

12D-13C: os enigmas pitagóricos; os aduladores;

13C-E: apelo à tolerância dos pais, que devem ser compreensivos e capazes de aliar a delicadeza à severidade;

13E-14A: o casamento;

14A-C: os pais devem ser modelos; conclusão.

Do primitivo sentido de "criação" ou "acto de tratar de uma criança até ela atingir o seu desenvolvimento", a paideia adquire, desde o século $\mathrm{V}$ a. C., o significado de "cultura" (por oposição a techne), designando, ainda, "educação", "formação" ou "instrução", isto é, um processo evolutivo de aquisição de conhecimentos, que modela e aperfeiçoa o homem. Por ter acepçóes diferentes em momentos históricos também eles distintos, dificulta a sua equiparação à nossa ou a outra língua. Os Romanos, por exemplo, traduziram-na por humanitas (Cícero e Varrão), mas foram os vocábulos disciplina e doctrina que prevaleceram.

Paideia não traduz apenas uma memória pedagógica, mas define a mentalidade, as atitudes, as experiências, as manifestaçóes e os ensinamentos, in lato sensu, os ideais da cultura helénica. 
DA EDUCAÇÁAO DAS CRIANÇAS 


\section{No t a Pré v Ia}

Para a tradução, seguimos como texto de referência a ediçáo de W. R. Paton, M. Pohlenz, H. Wegehaupt \& H. Gärtner (1993), Plutarchus: Moralia vol. 1, Stutgardiae et Lipsiae, Teubner. 
1. Pois bem, atentemos no que há a dizer sobre IA a educação das crianças de condição livre e a quem se poderá recorrer para as tornar virtuosas ${ }^{1}$.

2. Talvez seja melhor, em primeiro lugar, começar pelo nascimento. Aos pais que desejam, certamente, ter filhos distintos, eu aconselho que não se relacionem com as primeiras mulheres que encontrem, como as heteras ou as concubinas ${ }^{2}$. A vergonha indelével de uma origem

${ }^{1} \mathrm{O}$ autor sintetiza a intenção de abordar a educação (agoge) das crianças eleutheroi (por oposição a aneleutherios), ou seja, dos cidadãos livres, e de aconselhar os pais no sentido de proporcionarem uma formação moral aos seus filhos. Refira-se, ainda, em relação à questão da autenticidade deste tratado, que não é muito habitual Plutarco, nos restantes tratados das Obras Morais, introduzir a temática principal de forma tão directa.

${ }^{2}$ Cf. 5A; o autor detém-se, sobretudo, no aspecto social da génese das crianças, que poderia constituir um estigma pouco benéfico para o futuro dessas crianças, defendendo, por isso, um genos endoxon, a engeneia. Note-se que o autor do tratado refere-se às relaçóes dos pais (pateres) com heterai e pallakai, relaçóes que eram consideradas normais e que tinham enquadramento legal. Quanto às mães (materes), tal conduta seria condenada por se tratar de adultério (moicheia), daí que os conselhos se dirijam sobretudo aos pais, uma vez que estes se poderiam relacionar, caso o quisessem, com mulheres que se dedicavam à prostituição. Sobre a relaçáo 
в duvidosa, seja da parte da mãe ou do pai, acompanha a linhagem para toda a vida e torna-se presa daqueles que querem acusar e injuriar. Era sábio o poeta que disse: ${ }^{3}$

Quando o alicerce de uma família não é fundado com rectidão, o destino será desgraçado para a descendência.

Com efeito, o bom nascimento é um tesouro precioso para se poder falar livremente $e^{4}$. Por esse motivo, devem prestar muita atenção a isto os que desejam ter filhos de acordo com a lei. Além disso, o espírito dos que têm uma ascendência vil e enganadora cai, naturalmente, na desgrac ça e deixa-se humilhar. Muito justamente, disse o poeta:

Ainda que tenha um espírito arrojado, o homem é escravo quando tem consciência dos vis actos da máe e do pai. ${ }^{5}$

com heterai e pallakai e a sua legalidade, vide D. Leão (2005: 5-31, esp. n. 11).

${ }^{3}$ Eurípides, Hércules Furioso 1261-2; Ao contrário do que sucede neste caso, Plutarco, quando introduz uma citação por ToเๆTńs, refere-se a Homero (cf. A virtude moral 442D, A tranquilidade da alma 475A, A tagarelice 504D e 506A). Nas Obras Morais, o tema dos elementos ou traços de carácter que são herança familiar é também tratado ( $O$ controlo da ira $562 \mathrm{~B}$ ); em Como distinguir o adulador do amigo 63E (criança que nasce semelhante aos pais); em $O$ controlo da ira 563A, adverte que um bom homem pode nascer de um mau homem; tal como em Como deve o jovem ouvir poesia 28C refere que um bom filho pode nascer de um mau pai; cf. F. Albini (1997); no prólogo da biografia do orador Demóstenes, Plutarco afirma que para praticar a virtude não é preciso nascer numa grande e célebre cidade, pois ele próprio havia nascido numa cidade pequena.

${ }^{4}$ A eugeneia parece ser um requisito para a parrhesia ("liberdade de falar").

${ }^{5}$ Eurípides, Hipólito 424-5. 
Pelo contrário, os que descendem de pais distintos enchem-se de orgulho e soberba. Por exemplo, dizem que Diofanto ${ }^{6}$, filho de Temístocles, afirmou variadíssimas vezes a muitos que o seu desejo coincidia com o do povo ateniense ${ }^{7}$. De facto, o desejo dele era o desejo da mãe; o da mãe, o de Temístocles; o de Temístocles, o de todos os Atenienses. São muito dignos de louvor pela grandeza de sentimentos também os Lacedemónios, eles que puniram com uma multa o seu próprio rei, Arquedamo ${ }^{8}$, porque, como rei, ousou tomar em casamento uma mulher de baixa condição", o que levou os Lacedemónios a anunciar que ele não pensava ter reis mas reizinhos.

3. Poderia estabelecer uma relação que não foi desdenhada por outros autores antes do nosso tempo. De que estou a falar? É muito conveniente que aqueles que se aproximam das mulheres por causa da procriação se abstenham em absoluto do vinho ou que, pelo menos, bebam com moderação. Na verdade, os homens que amam o vinho e se embebedam com facilidade são aqueles cujos pais, no momento da procriação, estavam sob o efeito da bebida ${ }^{10}$. Como Diógenes, que ao ver

${ }^{6}$ Terá sido um dos discípulos de Amónio, mestre de Plutarco. Cf. J. Sirinelli (2000: 42-3). Apesar de o texto referir o nome de Diofanto, em Platão, Ménon 93d, e na Vida de Temístocles 2.1, de Plutarco, atribui o nome Cleofanto ao filho de Temístocles.

${ }^{7}$ Cf. Plutarco, Vida de Temistocles 18.7, Vida de Catão Censor 8.5, Apotegmas sobre reis e imperadores 185D.

${ }^{8}$ Arquedamo II (c. 468-427 a. C.).

${ }^{9}$ Plutarco, reportando-se a Teofrasto, refere-se a este casamento na Vida de Agesilau 2.6.

${ }^{10}$ A ideia de que o carácter das crianças pode ser afectado pelas circunstâncias em que ocorre a concepçáo, aparece desde cedo 
um jovem extasiado disse: "Jovem, o teu pai quando te concebeu estava embriagado" ${ }_{11}$. Ocupei-me, até aqui, de assuntos relacionados com a concepção, falarei agora sobre a educação ${ }^{12}$.

4. De uma forma geral, aquilo que se diz sobre a virtude é o que costumamos afirmar sobre as artes e as ciências; para uma conduta justa é necessário congregar, em absoluto, três elementos: a natureza, a razão e o costume ao exercício ${ }^{13}$. Chamo razão à aprendizagem ${ }^{14} \mathrm{e}$ costume à prática ${ }^{15}$. Os princípios advêm da natureza e os progressos da educação; a prática advém dos exercíB cios e a perfeição resulta de todas estas coisas. Porém, se, por destino, faltasse alguma destas coisas, a virtude ficaria imperfeita. É que, de facto, a natureza sem instrução é cega ${ }^{16}$, do mesmo modo que a instrução separada da

na cultura grega; a este propósito, vide Hesíodo, Trabalhos e Dias 735-6, 783-6, 792-5, 812-813 e Platão, Leis 775b-e; também Plutarco alude a esta matéria em No banquete 653D e 653F. Sorano, por exemplo, acreditava que uma mulher com excesso de álcool no acto de concepção poderia gerar uma criança com deformaçóes (Ginecologia 1.39, 2.44).

${ }^{11}$ Frg. 274 Mullach.

12 Agoge.

13 Sobre a doutrina dos três elementos (physis, logos e ethos), vide, por exemplo, Platão, Ménon 70a, Fedro 269d, Protágoras 323d; Aristóteles, Política 1134a e 1332a, Ética a Nicómaco 1103a 16 ss., 1179b; Xenofonte, Memoráveis 3.9.2, 2.6.39 e 3.3.11; Lucrécio, Sobre a natureza das coisas 3.319 ss.; por fim, recordamos as palavras que Plutarco escreveu Sobre o amor para com os filhos 495C: "Por natureza, nós somos um animal racional e social com uma concepção de justiça e lei”.

${ }^{14}$ Mathesis.

${ }^{15}$ Askesis.

${ }^{16}$ Plutarco desenvolve em algumas das suas biografias o tema da natureza e o papel modelador que a educação exerce nela. Por 
natureza é insuficiente e o exercício separado das duas não produz resultados. Tal como para a agricultura é necessário, em primeiro lugar, haver uma terra fértil e depois um agricultor sabedor e sementes adequadas, assim também a natureza é semelhante à terra, o educador ao agricultor e os ensinamentos e os preceitos à semente ${ }^{17}$. Eu poderia dizer, insistindo, que todas estas coisas se reúnem e contribuem para as almas dos que são venerados por todos, como Pitágoras, Sócrates, Platão ${ }^{18}$ e todos aqueles que, igualmente, alcançaram uma glória eterna. Se um dos deuses dá tudo isto a alguém, essa pessoa será, sem dúvida, feliz e afortunada. Se há alguém que pense que os que não tiveram um bom nascimento náo poderiam corrigir, tanto quanto possível, um defeito congénito, mediante a aprendizagem e o exercício vocacionados para a virtude, saiba que incorre num grande erro. Na verdade, a indolência corrompe a natureza predisposta para a virtude, enquanto a instrução corrige a ignorância. $\mathrm{O}$ que é fácil foge daqueles que são negligentes e o que é difícil é conquistado pela aplicação ${ }^{19}$.

exemplo, no bios de Coriolano (1.3), é bastante esclarecedor: "O próprio Márcio deu razão aos que pensam que a natureza, embora seja nobre e boa, se carece de educaçáo, produz juntamente com excelentes frutos outros defeituosos e de má qualidade, como ocorre na agricultura com o solo fértil que não se cultiva."; cf. Platão, República 491a-e.

${ }^{17}$ A analogia do processo agrícola com a educação permite introduzir, após a tríade (physis, logos e ethos), mais três elementos: a agricultura e o agricultor (georgia e georgos), o educador (paideion) e os ensinamentos ou preceitos (hypothekai e parangelmata).

${ }^{18}$ Note-se a escolha de três homens que se dedicaram à filosofia, que é requisito para a arete.

${ }^{19}$ Cf. Plutarco, Sobre ter um grande número de amigos 98A. 
D Pode constatar-se como o empenho é eficaz e que a aplicação e a fadiga são consequentes, observando vários exemplos: as gotas de água furam as rochas ${ }^{20}$; o ferro e o bronze desgastam-se ao serem manuseados; as rodas dos carros logo que se curvam náo podem, aconteça o que acontecer, tomar a direcção recta do início. É, de facto, impossível endireitar os bastôes curvos dos actores, mas o que é contra a natureza torna-se mais forte do que o que está de acordo com a natureza. São estes os únicos exemplos que mostram a força da aplicação? Não, existem dezenas de milhares.

A terra é, por natureza, boa. Porém, sendo neE gligenciada, fica estéril, e quanto melhor é a sua natureza tanto mais empobrece por ficar abandonada, acabando por se tornar inculta. Mas uma terra que é dura e mais rude do que convém, sendo cultivada, produz, de imediato, frutos generosos. Que árvores ${ }^{21}$, depois de abandonadas, não produzem frutos defeituosos ou secam infecundas e, quando recebem o trato correcto, não passam a ser fecundas e produtivas? Que força do corpo náo se desvanece ou se corrompe por causa do descuido, da languidez e da má constituição física? Que natureza débil, pelo contrário, não adquire mais força com o exercício e os combates? Que cavalos bem doma-

F dos não se tornam obedientes aos cavaleiros?22 E aqueles que permanecem indomáveis não acabarão por se tornar violentos e irascíveis? É preciso outros exemplos de admiração, quando nós vemos que até os mais ferozes dos

${ }^{20}$ Cf. Ovídio, Arte de Amar 1.475-6.

${ }^{21}$ Cf. $4 \mathrm{C}$ e $9 \mathrm{~B}$.

${ }^{22}$ Cf. 12B. 
animais ficam, com esforço, domados e domesticados? À pergunta: "quem são os mais pacíficos dos Tessálios?", um Tessálio responde com razão: "Os que deixam de guerrear”. É necessário dizer mais alguma coisa?

De facto, o carácter é um hábito consolidado ao longo do tempo ${ }^{23}$; se alguém definir como hábito as qualidades do carácter, não deve pensar que se enganou. Darei ainda um exemplo sobre isto e depois termino este assunto. Com efeito, Licurgo ${ }^{24}$, o legislador dos Lacedemónios, tomando dois cachorros dos mesmos pais, criou-os de forma diferente; a um fê-lo guloso e voraz, ao outro tornou-o capaz de seguir uma pista e caçar. Depois, um dia em que os Lacedemónios se reuniram, ele disse: "Lacedemónios, o que engrandece muito a importância da virtude são os hábitos, os princípios educativos, as liçóes e a conduta de vida; eu mostrarvos-ei, de seguida, a evidência destas coisas". Então, aproximando-se dos dois cachorros, libertou-os, depois de ter colocado no meio deles um prato e uma lebre. Um dirigiu-se para a lebre, o outro precipitou-se para

${ }^{23}$ Note-se a identificação do $\hat{\theta} \theta$ os com o É$^{\prime}$ os, como era habitual em Aristóteles (Ética a Nicómaco 1103a e EE 1220a; cf. Plutarco, A virtude moral 443C, A curiosidade 520D, As delongas da justiça divina 551E, 459B.

${ }^{24}$ Plutarco, na Vida de Sólon 16.2, descreve-o com as seguintes palavras: “(...) era o undécimo descendente de Héracles e fora, durante muitos anos, o soberano dos Lacedemónios e gozava de grande estima, amigos e poder, com os quais contou e cujo apoio pôs ao serviço do governo. E usando a força de preferência à persuasão, a ponto de perder uma vista, empreendeu a melhor medida para garantir a salvação e concórdia de uma cidade: que, entre os cidadãos, ninguém fosse nem pobre nem rico" (trad. de Delfim Leão (1999), Plutarco. Vida de Sólon, Lisboa). 
o prato. Os Lacedemónios, porém, não eram capazes de perceber o que isto queria dizer e o que o episódio dos cachorros significava. Licurgo, entáo, explicou: "Os dois nasceram dos mesmos pais, mas, por terem recebido uma educaçáa ${ }^{25}$ diferente, um tornou-se guloso e o outro caçador" ${ }^{26}$. Sobre os costumes e os modelos de vida, estes exemplos são suficientes.

5. Vou agora falar sobre a alimentação ${ }^{27}$. É necesc sário, assim penso, que as próprias mães alimentem os filhos e os amamentem. É que elas alimentá-los-ão com mais ternura e diligência, porque amam os filhos no seu íntimo, como se costuma dizer, "desde as unhas" 28 . As mulheres que cuidam das crianças e as amas de leite têm uma indulgência enganosa e fraudulenta, uma vez que amam por causa do salário. Na verdade, a natureza mostra que é necessário que as próprias mães amamentem e alimentem as crianças que deram à luz. É por causa

${ }^{25}$ Agoge.

${ }^{26}$ Esta história aparece também em Plutarco, Apotegmas espartanos 225F-226A-B, mas acrescenta-se uma versão diferente

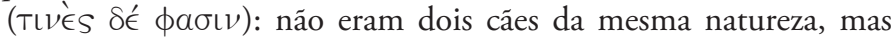
um estava habituado a viver em casa e o outro era caçador; o primeiro foi treinado a caçar e o outro a ter uma vida mais dedicada à gulodice (lichneia); como os dois se dirigiram àquilo a que se tinham acostumado, parece evidente o contributo da educação tanto

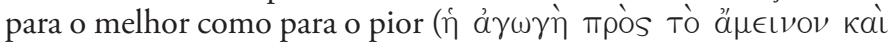

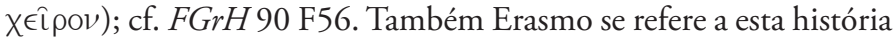
de Licurgo no seu tratado De pueris instituendis 29.95 (nulli non decantatum exemplum Lycurgi).

${ }^{27}$ трофท́: no contexto educacional, esta palavra traduz a alimentação ou a educação recebida no seio familiar durante os primeiros sete anos, ou seja, antes da formação escolar, estando dessa forma o seu sentido mais ligado à componente física.

${ }^{28} \mathrm{Ou}$ seja, "desde o tempo em que as unhas eram tenras", isto significa que os amam desde tenra idade. 
disto que dota de uma alimentação à base de leite todos os animais que dão à luz. É sábia a providência. Deu dois seios às mulheres, para que, no caso de nascerem gémeos, tivessem uma dupla fonte de alimento. À parte disto, elas seriam mais benévolas e carinhosas com os filhos e, por Zeus!, com razão. $\mathrm{Na}$ verdade, o facto de crescerem juntos reforça os laços afectivos. Os animais, por exemplo, quando se separam daqueles com quem comiam, sentem saudades. Defendo, em absoluto, que as próprias mães devem alimentar os filhos. Se, por acaso, não forem capazes, por causa de uma enfermidade física (esta circunstância poderá suceder) ou por estarem a preparar o nascimento de outros filhos, não se devem escolher ao acaso as mulheres que cuidam das crianças e as amas de leite. $\mathrm{O}$ melhor é escolher as mais virtuosas. Em primeiro, com costumes à maneira grega. Tal como é necessário que os membros do corpo das crianças sejam modelados, correctamente, desde o nascimento, para que cresçam direitos e sem defeito, assim também convém, desde o início, orientar os costumes das crianças. Em verdade, a infância é fácil de formar e é flexível, pois ainda se consegue dissolver os ensinamentos nas almas delicadas das crianças. O que é duro dificilmente se suaviza. Tal como os selos se imprimem na cera delicada, também os ensinamentos nas almas dos que ainda são crianças. Parece-me que o divino Platão ${ }^{29}$, de forma apropriada, aconselha as amas a não contarem às crianças um conto qualquer, para que náo suceda que as suas almas se manchem, logo de início, com loucuras ou

${ }^{29}$ Cf. República 377b-c. 
corrupçôes. O poeta Focílides ${ }^{30}$ refuta isto muito bem ao aconselhar:

\author{
É necessário que ainda na infância \\ aprendam as acçóes virtuosas.
}

6. É por isso que não convém descuidar o seguinte: os jovens escravos que estão destinados a servir os filhos desses pais e a acompanhá-los devem ser escolhidos, 4A acima de tudo, pelo seu carácter virtuoso e, com certeza, devem falar a língua grega com fluência, para que, com o convívio junto de bárbaros com costumes perversos, eles não se deixem contagiar pelos seus vícios. Os que falam por meio de provérbios dizem, com verdade, que "quem vive perto de um coxo, aprende a coxear".

7. Quando as crianças atingirem a idade de serem entregues aos pedagogos ${ }^{31}$, deve ter-se, nesse momento, muito cuidado na sua escolha, a fim de não se permitir que os filhos sejam entregues a escravos bárbaros ${ }^{32}$ ou desequilibrados. Pois, o que hoje muitas pessoas fazem

в é extremamente ridículo. De entre os escravos diligentes nomeiam os agricultores, os armadores de barcos, os comerciantes, os administradores e os usurários ${ }^{33}$. Mas, se descobrem um escravo ébrio e guloso, inútil para qualquer actividade, é a esse que levam os filhos e os confiam. É necessário, contudo, que o pedagogo sério tenha

${ }^{30}$ Focílides de Mileto (séc. VI a. C.).

${ }^{31}$ Aos 7 anos.

${ }^{32}$ Recorde-se que os paidagogoi eram, em geral, escravos. Segundo Platão, Lisis 223a, muitos desses paidagogoi seriam não-gregos a desempenhar essas funçóes.

${ }^{33} \mathrm{Ou}$ agiotas. 
a natureza como a de Fénix, o pedagogo de Aquiles ${ }^{34}$. Vou expor a questão mais importante de todas as que até agora referi. Procurem-se para os filhos mestres que tenham uma conduta de vida irrepreensível, uma moral acima de qualquer censura e que sejam os melhores pela sua experiência. A fonte e a raiz da honestidade perfeita encontram-se na educação conforme aos bons costumes. Tal como os agricultores póem esteios nas plantas, assim os mestres, que têm bons hábitos, enxertam nos jovens os princípios e os conselhos convenientes, para que brote neles um carácter recto. É possível, porém, condenar alguns dos pais de hoje que, antes de avaliar os que devem ensinar, por ignorância ou também por inexperiência, entregam os filhos a homens de má índole e pouco fiáveis. Se os pais agem por inexperiência, isso não é apenas ridículo, mas antes o cúmulo do absurdo! De que forma?! Algumas vezes ${ }^{35}$ têm conhecimento ou então percebem por aquilo que outros dizem — da inexperiência aliada à perversidade de alguns mestres, e mesmo assim entregam-lhes os filhos, seja porque não são capazes de resistir a tratá-los com adulaçóes, seja

${ }^{34}$ Cf. Ilíada 9. 442-3. Note-se que o autor recorre a um exemplo mitológico, a relação entre Fénix e Aquiles, remetendo-se a figura do pai, Peleu, para um plano secundário. Quando se aborda a questão da paideia e dos seus agentes, é recorrente surgir na Literatura Grega a referência ao paidagogos de Aquiles: vide, por exemplo, Platão, República 390e ou Plutarco, Vida de Alexandre 5.8 e 24.10 .

${ }^{35} \mathrm{O}$ autor do tratado critica os pais que, irresponsavelmente, preferem fazer favores aos philoi, em vez de cuidarem da educação dos seus filhos. A história de Sócrates (cf. Clitofonte 407a, embora a versão seja distorcida, o que pode significar que não a tinha memorizada), que se segue, tem por intenção ilustrar isso (cf. 5A). 
para agradarem aos amigos que lhes pedem, agindo como quem, tendo o corpo doente, o descurasse, ainda que pudesse curá-lo com a ciência; ou como o homem que, só para agradar a um amigo, prefere escolher aquele que o deitará a perder por causa da inexperiência; ou como aquele que, a pedido do amigo, despede o melhor armador de barcos, como se o considerasse o pior.

Por Zeus e todos os deuses! Para aquele que merece ser chamado pai tem mais valor agradar aos pedidos ou à educação dos seus filhos? Sobre isto, o velho SócraE tes dizia, muitas vezes, que não é conveniente, ainda que fosse possível, subir à parte mais alta da cidade e gritar: "Homens, onde ides? Fazeis todo o esforço para adquirir a riqueza, porém pouco vos preocupais com os filhos. Que coisas abandonastes por eles?". Pela minha parte, posso aduzir a estes factos que esses pais agem de forma semelhante à daquele que, por um lado, se preocupa com o calçado e, por outro, tem pouco cuidado com o pé ${ }^{36}$. Muitos pais valorizam tanto o amor ao dinheiro $^{37}$, juntamente com o desamor aos filhos, que, para

F não gastarem um salário elevado, escolhem homens de modo algum válidos para educadores dos filhos, procurando uma ignorância que fique barata. Também Aristipo zombou num discurso, não sem elegância, mas, sem dúvida, com fineza, de um pai privado de inteligência e de coraçãa ${ }^{38}$. Depois de ele perguntar a Aristipo que

${ }^{36}$ Refere-se ao 'tamanho do pé'; cf. Plutarco, A tranquilidade da alma 466E.

${ }^{37}$ Sobre o dinheiro na educação, vide Platão, Apologia 19d-e e $20 \mathrm{~b}$.

${ }^{38}$ No tratado $A$ vida de dez oradores 838A, atribui-se uma 
salário pediria para a educação do filho, respondeu "mil dracmas". "Por Héracles", disse, "como é excessivo o teu pedido. Na verdade, com mil dracmas posso comprar um escravo". "Dessa forma", replicou Aristipo, "terás dois 5A escravos, o teu filho e aquele que puderes comprar". Em geral, não é ridículo habituar as crianças a comer com a máo direita, e, se estenderem a esquerda, repreendê-los, não tendo, depois, qualquer preocupação em ouvir os ensinamentos correctos e segundo os bons costumes? ${ }^{39}$ Que acontece com estes pais maravilhosos, depois de criarem e educarem mal os filhos? Eu passo a explicar. Quando os filhos chegam à idade adulta, descuidam por completo a vida saudável e disciplinada, e, ao invés, abandonam-se aos prazeres libertinos e servis; os pais, então, arrependem-se de ter negligenciado a educação dos filhos e, quando já de nada serve, afligem-se com as faltas destes. Com efeito, alguns dos pais escolhem para os filhos aduladores e parasitas, homens inqualificáveis e execráveis, que corrompem e maltratam a juventude; outros compram heteras e meretrizes ${ }^{40}$ arrogantes, que cobram preços exorbitantes; outros perdem-se em banquetes; outros arruínam-se nos jogos mais imprudentes: relações adúlteras e ritos báquicos, condenandose à morte por um único momento de prazer. Se, pelo contrário, tivessem sido entregues a um filósofo, talvez

história semelhante a Isócrates; com este relato pretende-se provar que um indivíduo apaideutos (sem educação ou cultura) não é mais do que um escravo.

${ }^{39}$ Cf. Plutarco, A fortuna 99D; vide ainda Pode a virtude ensinar-se? 439F-440A.

${ }^{40}$ Chamaitypai (cf. 13B): além de hetairai e pornai, este é outro termo para designar as 'prostitutas'. 
c não se sentissem atraídos por tais práticas e, pelo menos, aprenderiam a advertência de Diógenes que aconselha com palavras rudes mas verdadeiras: "Dirige-te a um lupanar para aprenderes que as coisas dignas de honra não se distinguem das desprezíveis".

$\mathbf{8}^{41}$. Em resumo, eu afirmo (poderá parecer, com razão, que eu pronuncio oráculos e não conselhos) que no princípio, no meio e no fim existe algo de fundamental: uma conduta séria e uma educação obediente às leis pois defendo que todas estas coisas favorecem e auxiliam a obtenção da virtude e da felicidade ${ }^{42}$. Os outros bens são humanos, fúteis e indignos de atenção. A boa estirpe D é, seguramente, um bem, mas é um bem herdado dos progenitores; sem dúvida que a riqueza é preciosa, mas é um bem fruto do acaso, posto que, muitas vezes, se afasta dos que a têm e vai ao encontro daqueles que não a esperam; uma grande riqueza é um objectivo para aqueles que desejam alcançar as bolsas, os criados perversos e os sicofantas ${ }^{43}$, e, o pior, encontra-se também entre os mais perversos. A glória é, seguramente, algo venerável, mas inconstante; a beleza é desejável, mas passageira; a saúde é preciosa, mas perecível; a força é invejável, mas diminui na doença e na velhice. Ou seja, se alguém se orgulha da força do corpo, logo que dá conta do engano compreende a força da inteligência. Pois, qual é o poder

${ }^{41}$ Cf. T. Morgan (2000r: 248) sobre 5C-E.

${ }^{42}$ Cf. Aristóteles, Ética a Nicómaco 1172a.

43 Sykophantes: termo que designa o denunciante, ou seja, aquele que para conseguir algum benefício pessoal acusava outro indivíduo, recorrendo por vezes à calúnia ou a estratagemas pouco lícitos. 
da força humana comparado com o dos outros animais? Como o dos elefantes, dos touros e dos leóes? A formação é o único dos bens que temos que é imortal e divino ${ }^{44}$. Na natureza humana, os dois bens mais importantes são a inteligência e o raciocínio ${ }^{45}$. A inteligência comanda o raciocínio e o raciocínio está ao serviço da inteligência. $\mathrm{O}$ raciocínio, por sua vez, não se perturba com a sorte, não se pode tirar pela calúnia, é incorruptível na doença e não se injuria na velhice. $\mathrm{Na}$ verdade, apenas a inteligência, ao envelhecer, se rejuvenesce. $\mathrm{O}$ tempo, que tira todas as coisas, concede na velhice o conhecimento $^{46}$. A guerra, como uma torrente ${ }^{47}$, arrasta toda a justiça e leva tudo à frente, só não pode destruir a formação. Parece-me que o filósofo Estílpon, natural de Mégara, quando Demétrio ${ }^{48}$, após ter subvertido os fundamentos da cidade ${ }^{49}$ reduzindo-a à escravidáo, lhe perguntou se tinha perdido alguma coisa, respondeu de forma digna de ser recordada ao dizer: "Claro que náo. A guerra náo leva como despojo a virtude" ${ }^{50}$. A resposta de Sócrates parece que está de acordo e se harmoniza com esta ${ }^{51}$. Também a ele, perguntando-lhe Górgias,

${ }^{44}$ Cf. Platão, Leis 644b; Isócrates, Para Demónico 19; Plutarco, Como deve o jovem ouvir poesia 30F.

${ }^{45}$ Nous e logos, respectivamente; cf. Aristóteles, Política 1334b e Plutarco, Da fortuna 98C.

46 Sobre a valorização da experiência e do conhecimento na velhice, vide Sólon, frg. 18 West e Platão, Banquete 219a e Leis 715 d-e.

${ }^{47}$ Igual símile em Plutarco, Vida de Pompeio 19.7.

${ }^{48}$ Cf. Plutarco, Vida de Demétrio 9.8-9.

${ }^{49}$ Refere-se à cidade de Mégara.

${ }^{50}$ Cf. Plutarco, A tranquilidade da alma 475C.

${ }^{51}$ Cf. Platão, Górgias 407d-e. 
parece-me, que opiniáo tinha sobre o grande rei e se o considerava feliz, respondeu "nada sei sobre a sua virtude e formação”, pois a felicidade está nestas coisas e não nos bens fortuitos.

9. Da mesma maneira que sustento que não há nada mais vantajoso do que a educação dos filhos ${ }^{52}$, afirmo também, uma vez mais, ser necessário eles terem uma educação incorrupta e sã, com o objectivo de afastá-los o mais possível de conversas frívolas. Com efeito,

в agradar a muitos é desgostar os sábios. Também Eurípides secundou as minhas palavras ao escrever: ${ }^{53}$

Eu sou rude a pronunciar discursos para uma multidão, mas sou mais hábil quando o faço para poucos iguais a mim. Tem o destino destas coisas! Na verdade, os que têm uma sabedoria frívola falam mais habilmente para uma multidão.

Pela minha parte, tenho observado que se aplicam a falar para uma multidão de forma agradável e requintada, e, em muitos casos, levam uma vida dissoluta e lasciva. E, por Zeus, é compreensível! De facto, se negigenciam o bem com a preparação de prazeres, com dificuldade colocariam o que é recto e são acima do deleite e comodidades pessoais, para, desta forma, poderem c procurar o que é sensato em vez do prazer. Depois disto, o que se pode dizer às crianças? ${ }^{34}$ Não é, com certeza,

${ }^{52}$ Depois de ter introduzido o tema da paideia, o autor passa a desenvolver duas áreas fundamentais da formação: a retórica e a filosofia.

${ }^{53}$ Hipólito 986-9.

${ }^{54}$ Lacuna textual nesta interrogativa; vide definição socrática de retórica em Platão, Górgias 462c. 
sensato nem dizer nem fazer nada ao acaso; como diz o provérbio, "as coisas boas são difíceis" ${ }^{55}$. Os discursos improvisados estão repletos de tanta habilidade e superficialidade, que nem sabem por onde é necessário começar, nem onde acabar. Mesmo sem olhar a outros erros, os que falam de improviso caem em terríveis excessos e na abundância de palavras. A reflexão ${ }^{56}$, porém, não permite que o discurso ultrapasse a medida conveniente. Péricles ${ }^{57}$, "segundo nos legou a tradição", quando, repetidas vezes, era chamado pelo povo, não respondia ${ }^{58}$, alegando não estar preparado. Também Demóstenes ${ }^{59}$, que tinha admiração pela acção política de Péricles, recusouse a falar quando os Atenienses lhe pediram um conselho, dizendo: "não estou preparado". No entanto, estas coisas talvez sejam de uma tradição anónima e forjada. Porém, em Contra Midias ${ }^{60}$, defende, com clareza, a utilidade da reflexão. Afirma, por exemplo: "Atenienses, eu confesso ter meditado e náo posso negar que me preparei o mais que me foi possível. Pois seria um desgraçado, se, perante o que sofri e ainda sofro, negligenciasse

${ }^{55} \mathrm{O}$ mesmo provérbio pode encontrar-se em Platão, República 435c, 497d, Crátilo 384a e Hipias Maior 304e; Demóstenes, Contra Aristócrates XXIII.

${ }^{56}$ Sobre falar de forma reflectida, vide Quintiliano 10.6.

${ }^{57}$ Cf. Plutarco, Vida de Péricles 7.7 e 8.6.

${ }^{58}$ Cf. Plutarco, Conselhos Politicos 811C-D e 812C-D.

${ }^{59}$ Plutarco, Vida de Demóstenes 9.2 confirma a influência que Péricles teve na relutância de Demóstenes em falar de improviso; vide também Plutarco, Vida de Demóstenes 3.1 e 11.7, e Demóstenes, Contra Midias XXI. 191.

${ }^{60}$ Obra de Demóstenes que Plutarco cita diversas vezes: e. g. Vida de Alcibiades 10.4, Vida de Demóstenes 12.3-6, Conselhos Políticos 817C. 
o que vos devo dizer”. A necessidade de condenar, em absoluto, os discursos improvisados e de não os praticar, mesmo de forma moderada, eu não a defendo, mas que se faça isso da mesma maneira que se usa um fárma$\mathrm{co}^{61}$. Até à idade adulta náo julgo conveniente falar sem preparaçáo, mas apenas quando se consolide o talento; nesse momento, pode alguém exprimir-se livremente, quando a ocasiáo pedir. Tal como os que estâo durante muito tempo presos e que, mesmo após serem libertados, não conseguem caminhar por não ultrapassarem o longo hábito das algemas, também os que adoptam uma

F forma de discurso durante muito tempo, se for necessário falarem de improviso, não conservam menos esta marca. Ao contrário, deixar falar de improviso aqueles que ainda são crianças é a causa para haver linguagem vã e extrema. Um mau pintor de animais - contam - mos-

$7 \mathrm{~A}$ trando a Apeles ${ }^{62}$ um quadro, disse "este pintei-o num instante", o outro respondeu "Mesmo que o não tivesses dito, eu sei que foi pintado depressa. Admiro-me como não pintaste mais quadros destes".

Da mesma maneira que, efectivamente, - regresso, desta forma, ao tema inicial do discurso - não aconselho um estilo teatral e excessivamente trágico, recomendo também evitar e fugir de um estilo pobre e indigno ${ }^{63}$. Se o estilo empolado é impopular, o que carece de adornos náo tem qualquer impacto. Tal como

${ }^{61}$ Cf. Platáo, República 382c, 389b, 459d. IV a. C.

${ }^{62}$ Apeles de Cólofon, pintor grego da segunda metade do séc.

${ }^{63}$ Estas deficiências de estilo eram criticadas pela escola peripatética. 
o corpo deve não só ser saudável mas também forte, da mesma forma o discurso deve estar isento de erros e, ao mesmo tempo, ser vigoroso ${ }^{64}$. A prudência é apenas louvada, enquanto a audácia se admira. Tenho a mesma opinião sobre a disposição da alma. Não convém, na realidade, que seja arrogante, tímida ou receosa. Pois uma atitude conduz à imprudência e a outra à escravidão. Pelo contrário, a arte e a harmonia residem em manter o meio termo, em todas as ocasióes. Quero, assim, enquanto ainda me ocupo da educação, darei sobre ela a minha opiniáo- dizer que fazer um discurso com um estilo pouco variado ${ }^{65}$ é, em primeiro lugar, um sinal claro de ignorância. Depois, julgo que, na prática, é, sem dúvida, cansativo e não perdura. Com efeito, a monotonia é aborrecida e desagradável, enquanto a diversidade é sedutora ${ }^{66}$, como acontece em todas as outras coisas, como, por exemplo, nos espectáculos musicais e teatrais ${ }^{67}$.

10. É necessário, pois, que a criança de condição $\operatorname{livre}^{68}$ não deixe de ouvir e de observar qualquer uma das disciplinas que integram a chamada cultura geral, mas deve aprendê-las de passagem ${ }^{69}$, para passar a gostar

${ }^{64}$ Cf. 9B; vide Plutarco, Como perceber os próprios progressos da virtude 79B e Aristófanes, As Rãs 939 ss.

${ }^{65}$ Monokolos, à letra 'de um só membro' (Cf. Aristóteles, Retórica 1409b13-17); portanto um período exíguo, reduzido, pouco variado.

${ }^{66}$ Vide no texto a oposição entre $\mu 0 \nu \omega \delta$ ía (monotonia) e тоскц $\lambda i ́ a$ (variedade).

${ }^{67}$ Cf. Xenofonte, Banquete 2.2; Aristóteles, Ética a Nicómaco $1174 \mathrm{~b}$ e Política $1336 \mathrm{~b}$.

${ }^{68}$ Cf. 1A.

${ }^{69}$ Cf. Aristóteles, Política 1337b15-17. 
delas (pois é impossível ser completo em tudo), e deve venerar a filosofia ${ }^{70}$. Posso, por meio de uma imagem, fundamentar a minha própria opiniáo. Como é belo viajar por muitas cidades, assim é útil habitar na mais poderosa. Também o filósofo Bíon ${ }^{71}$ dizia, com elegância, que, como os pretendentes não se podiam aproximar de Penélope, se uniram às escravas dela ${ }^{72}$. Da mesma forma também os que não conseguem ter sucesso

D com a filosofia perdem tempo com outras disciplinas que não têm qualquer valor. Por isso, é necessário que a filosofia encabece a restante formação ${ }^{73}$. $\mathrm{Na}$ verdade, os homens inventaram duas ciências sobre o cuidado do corpo: a medicina e a ginástica. Uma traz a saúde, a outra o vigor físico. Para a alma que sofre de uma enfermidade, a filosofia é o único remédio ${ }^{74}$. Na verdade, graças a ela e com o seu auxílio é possível saber aquilo que é bom e inútil, justo e injusto, em resumo, o que se

${ }^{70}$ Nas biografias, Plutarco realçará o papel da filosofia na definição do carácter dos heróis. Por exemplo, Epaminondas era famoso pela sua educação e filosofia (Vida de Agesilau 27.3), e por isso conseguiu mais facilmente superar a adversidade; são assinalados também os progressos de Numa por causa da educação e da filosofia (Vida de Numa 3.5: "tornou-se mais civilizado por meio da educação, do sofrimento e da filosofia"); Péricles aprendeu com Anaxágoras (Sobre a importância de o flósofo falar com os governantes 777A); também Filopémen não ignorou os textos filosóficos para acrescentar algo à sua virtude (Vida de Filopémen 4.6-10).

${ }^{71}$ Filósofo cínico do séc. III a. C.

${ }^{72}$ Alusão às doze escravas de Penélope que se uniram, secretamente, aos pretendentes. Ulisses, no seu regresso a Ítaca, com a ajuda de Telémaco, o boieiro e o porqueiro castigou-as com a morte por enforcamento (Cf. Odisseia 22.417-473).

${ }^{73}$ Cf. Platão, Leis 643c.

${ }^{74}$ Cf. Platão, Górgias 464b-c; sobre a filosofia como medicina da alma, vide Cícero, Tusculanas 3.2 e Séneca, Cartas a Lucílio 8.2. 
deve escolher e evitar; como deve ser o relacionamento com os deuses, os pais, os idosos, as leis, os estrangeiros, os magistrados, os amigos, as mulheres, as crianças e os criados. Porque é necessário temer os deuses, honrar os pais, respeitar os idosos, observar as leis, obedecer aos magistrados, amar os amigos, ser moderado com as mulheres, ser terno com as crianças e não maltratar, rudemente, os escravos. E, o mais importante, não rejubilar, em excesso, na prosperidade, nem ficar muito aflito na desgraça; não se entregar por inteiro aos prazeres, nem ser precipitado ou furioso na cólera. Considero que estes sáo os mais importantes de todos os benefícios que provêm da filosofia.

Assim, agir com nobreza na prosperidade é a ati$\mathrm{F}$ tude digna do homem; não provocar inveja na prosperidade é a atitude do homem moderado; superar os prazeres com a razão é a atitude do homem sábio. Vencer a cólera não está ao alcance de um homem comum. Eu julgo que os homens perfeitos são os que podem unir e alternar a capacidade política com a filosofia; sou de opiniấo que são capazes de dominar os dois maiores bens: dedicar-se à actividade política para utilidade da vida pública e passar o tempo com calma e serenidade ocupando-se da filosofia ${ }^{75}$. Com efeito, dos três estilos ${ }^{76}$ de vida que há, o activo, o contemplativo e o votado aos

${ }^{75}$ Cf. Para E. Berry (1958: 388-9) este é o único elemento estóico do tratado, por propor uma simbiose entre a filosofia e a vida pública (exp. Péricles, Arquitas, Díon e Epaminondas); sobre a "filosofia activa”, vide Plutarco, Vida de Cícero 40.1-2.

${ }^{76}$ Cf. Aristóteles, Ética a Nicómaco 1095b-1096a e Politica $1324 \mathrm{a}$. 
prazeres, este último é dissoluto e escravo dos prazeres, e, além disso, de natureza animal e vulgar; o estilo contemplativo, logo que se engana na actividade, torna-se inútil; o activo, por sua vez, privado da filosofia, não tem arte e é defeituoso. Por isso, devemos esforçar-nos por participar com empenho nas actividades públicas e por nos entregarmos à filosofia de acordo com o que B as circunstâncias permitem. Assim exerceram os cargos políticos Péricles, Arquitas de Tarento ${ }^{77}$, Díon de Siracusa e Epaminondas de Tebas, sendo que os dois últimos foram discípulos de Platão. Sobre a educação não sei em que aspectos é necessário deter-me ainda; além de dizer que é útil, torna-se, sobretudo, crucial não negligenciar a aquisição de obras antigas, mas coleccionar estas como faz o agricultor ${ }^{78}$... De igual forma, o instrumento da educação é o uso dos livros e, deste modo, sucede que observamos, por meio deles, o conhecimento desde a fonte.

11. Não é, certamente, conveniente descuidar-se c o exercício do corpo $^{79}$, mas devem confiar-se as crianças ao pedótriba, a fim de se exercitarem de forma adequada por causa da harmonia ${ }^{80}$ e da força ${ }^{81}$ corporais, porque a base de uma boa velhice é um correcto cuidado

77 Filósofo e matemático pitagórico que por seis vezes foi eleito general da sua polis. Sabemos, ainda, que salvou Platão da perseguição de Dionísio II de Siracusa.

${ }^{78}$ Possível reconstituição da lacuna textual: "que procura ferramentas para a lavoura”.

${ }^{79}$ Para os Gregos, a educação do corpo era uma parte fundamental da paideia (cf. Platão, República 403c-412b, Leis 795d-796e)

${ }^{80}$ Eurythmia.

${ }^{81}$ Rhome. 
físico durante a infância. Tal como é necessário no bom tempo preparar-se a tempestade, da mesma maneira convém seguir-se, durante a juventude, a disciplina e a moderação como recurso para a velhice. Deste modo, deve-se regular o esforço corporal das crianças para se evitar que, por esgotamento, renunciem ao trabalho da educação. Na verdade, o sono e a lassitude, segundo Platão ${ }^{82}$, são inimigos do estudo. E porquê estes? Ora esta é, precisamente, a questão mais importante de todas as que desejo abordar. É necessário preparar as crianças para as lutas militares, exercitando-as no lançamento de dardos, de flechas e na caça. Pois, nos combates, "os bens dos vencidos estão destinados aos vencedores como prémio"83. A guerra não aceita que a boa constituição física seja desenvolvida com languidez e o soldado frágil, acostumado aos exércitos de atletas que não são belicosos, recusa os das lutas guerreiras ${ }^{84}$.

Alguém poderia dizer: "Que é isto? Tu prometeste dar conselhos sobre a educação das crianças de condição livre e descuidaste, manifestamente, a educação das crianças pobres e plebeias. Porventura concordas que se dê formação apenas aos ricos? Não é difícil responder a isso. Eu preferiria que esta educação aproveitasse realmente a todas as crianças de forma indiferente; contudo, alguns, que trabalham no campo, por falta de recursos não podem tirar proveito dos meus conselhos. Culpem a sorte e não quem os aconselha! Devem, porém, os

${ }^{82}$ República $537 \mathrm{~b}$.

${ }^{83}$ Xenofonte, Ciropedia 2.3. 2 e 7.1.13.

${ }^{84}$ Cf. Platão, República 556d; vide ainda Plutarco, Vida de Filopémen 3.4-5. 
pobres esforçar-se por, na medida do possível, dar aos filhos a melhor educação. Se não que lhes procurem dar aquilo que estiver ao seu alcance.

Acrescentei estas coisas ao meu discurso para, de seguida, referir outros elementos que contribuem para a educação justa dos jovens.

12. Digo, igualmente, que é necessário conduzirmos as crianças para os bons costumes por meio de

F conselhos e do diálogo e não - por Zeus! - com maus tratos e castigos. Parece-me que estes métodos convêm mais aos escravos do que às crianças de condição livre. Pois, desanimam e zangam-se com os trabalhos, quer por causa do sofrimento físico, quer pelas injúrias. Para

9A as crianças de condição livre, os elogios e as repreensóes são mais proveitosos do que todo o tipo de maus tratos, pois uns encorajam o bem e as outras afastam-nas do mal. É, assim, necessário que se alternem e diversifiquem as repreensóes e os elogios, e, quando as crianças são insolentes, apliquem-se castigos dignos e transmita-selhes, de novo, ânimo com elogios, e que imitem as amas que, quando as crianças choram, lhes oferecem novamente o seio para consolação. Convém, assim, que as crianças não se exaltem nem se tornem orgulhosas com os elogios. Pois, com os louvores excessivos enchem-se de vaidade e ficam displicentes.

13. Já conheci alguns pais que dedicam aos filhos um amor muito forte que é a causa da falta de amor ${ }^{85}$.

в $\mathrm{O}$ que é que eu posso dizer para, com um exemplo,

${ }^{85} \mathrm{Na}$ biografia de Catáo de Útica (37.3), Plutarco atribui esta sentença a Teofrasto. 
tornar este raciocínio mais claro? Desejando que os filhos tenham, rapidamente, a primazia em tudo, eles impóem-lhes trabalhos excessivos, com os quais caem desfalecidos, e, de resto, fatigando-se com estes sofrimentos, não recebem os conhecimentos de forma dócil. Pois, como as plantas se alimentam com a medida certa de água, mas se asfixiam com muita, da mesma forma a alma cresce com um trabalho adequado, mas afoga-se se este for em demasia. É conveniente dar às crianças um momento de descanso depois dos trabalhos contínuos ${ }^{86}$, se pensarmos que toda a vida se divide em momentos de descanso e de trabalho. Por esse motivo, não só se inventou a vigília, mas também o sono; não só a guerra, mas também a paz; não só a tempestade, mas também o bom tempo; não só o trabalho, mas também as festas. $\mathrm{O}$ que eu digo, em resumo, é que o descanso é o tempero do trabalho. Não é apenas possível ver isto entre os seres vivos, mas também entre as coisas inanimadas. Na verdade, também afrouxamos as cordas dos arcos e das liras para que as possamos esticar. De uma maneira geral, o corpo conserva-se com a necessidade e a satisfação, enquanto a alma com o repouso e o trabalho.

É justo repreender alguns dos pais que, depois de confiar os filhos a pedagogos e a mestres, não são testemunhas das lições dos filhos nem os ouvem, descuidando muito o seu dever. Eles próprios devem submeter os filhos a provas com regularidade e não ter confiança na disposição de ânimo de um assalariado. Pois também estes dão mais atenção às crianças quando têm o dever

${ }^{86}$ Cf. Aristóteles, Politica 1333a30-32. 
de prestar, em cada ocasiáo, contas do seu desempenho. O que é dito, com jocosidade, pelo palafreneiro vem aqui a propósito: nada engorda tanto o cavalo como o olho do rei ${ }^{87}$.

Deve-se, sobretudo, exercitar e acostumar a memória das crianças $^{88}$, pois ela é o tesouro da educaçãa ${ }^{89}$ e por isso diz a mitologia que Mnemósine é a mãe das Musas $^{90}$, dando a entender e insinuando que nada cria

E e alimenta como a memória. Assim, deve-se exercitá-la em ambos os casos: seja quando as crianças têm, por natureza, uma boa memória, ou seja quando, pelo contrário, se esquecem. Na verdade, num caso fortaleceremos a vantagem da natureza e no outro supriremos a insuficiência. Assim aquelas serão melhores do que as outras e estas irão elas próprias progredir. Hesíodo afirmou com razão:

Se, porventura, juntares pouco ao pouco

e fizeres isto com frequência, depressa terás muito" ${ }^{\text {11 }}$

Com efeito, não se esqueçam os pais de que a parte da instrução que diz respeito à memória contribui, e não é em porção pequena, não só para a educação,

${ }^{87}$ Cf. Xenofonte, Económico 12.20 e [Aristóteles], Económicos $1345 \mathrm{a} 2-5$.

${ }^{88} \mathrm{O}$ valor do exercício da memória é um topos recorrente da paideia grega: Platão, Protágoras 325e e Leis 811 a; cf. supra Da educação das crianças $2 \mathrm{C}$.

${ }^{89}$ Cf. Plutarco, Vida de Mário 46.2.

${ }^{90}$ Hesíodo, Teogonia 53-55.

${ }^{91}$ Trabalhos e Dias 361-362; a mesma citação é feita por Plutarco em Como perceber os próprios progressos da virtude $76 \mathrm{C}$. 
mas também para as actividades da vida. Na verdade, a $\mathrm{F}$ memória dos actos passados é um exemplo de prudência para situaçôes futuras ${ }^{92}$.

14. É óbvio que se devem afastar os filhos da linguagem obscena ${ }^{93}$. Segundo Demócrito, "a palavra é a sombra da acção" "94. Por conseguinte, devem preparar-se IOA para serem de carácter afável e amáveis. $\mathrm{Na}$ verdade, tal como um carácter náo sociável se torna odioso, do mesmo modo as crianças se tornam amáveis, se nas discussôes com os companheiros não forem completamente obstinadas. Com efeito, não é apenas belo vencer, mas também saber ser vencido naquelas ocasióes em que é prejudicial vencer. Como acontece, em verdade, na vitória cadmeia ${ }^{95}$. A propósito disto, posso aplicar o testemunho do sábio Eurípides, que diz:

Quando dois falam, e um se irrita,

o que não se opõe com palavras é o mais sábio. ${ }^{96}$

Há outras coisas, efectivamente, não inferiores às que já tratámos e, de igual modo, importantes, que os jovens devem praticar e que agora convém referir. São as seguintes: praticar uma vida modesta, moderar a linguagem, estar completamente acima da ira e dominar

${ }^{92}$ Aristóteles, Retórica 1368a30-31.

${ }^{93}$ Aristóteles, Política 1336b.

${ }^{94}$ Frg. B 145.

95 Provérbio mítico que se refere ao combate entre os dois irmãos Etéocles e Polinices. A vitória cadmeia: é aquela vitória que causa a ruína de quem vence (cf. Heródoto 1.166.2, Platáo, Leis 641c).

${ }^{96}$ Versos da tragédia Protesilau, segundo Estobeu 3.19.3. 
a força das mãos ${ }^{97}$. É necessário, agora, examinar o valor de cada uma destas coisas. Tornar-se-ão, no entanto, mais compreensíveis por meio de exemplos. Para começar pelo último, vejamos o caso de alguns indivíduos que, por se dedicarem a ganâncias ilegítimas, deitam a perder a reputação da sua vida passada. Gilipo, o Lacedemónio, por exemplo, é uma dessas pessoas, ele que, por desatar os saquinhos do dinheiro, foi desterrado de Esparta ${ }^{98}$. A tranquilidade é, na

c verdade, própria de um homem sábio. Sócrates, por exemplo, quando um jovem com muita audácia e desrespeito lhe deu pontapés, ao ver que os que o rodeavam estavam indignados e muito agitados, com a intençáo de perseguirem o jovem, disse: "Se um burro me desse coices, também considerarias digno que eu lhe desse coices?”. Aquele náo ficou, certamente, de todo impune, uma vez que se enforcou, por todos o injuriarem e o chamarem de "coiceador"99. Também Aristófanes, quando apresentou As Nuvens ${ }^{100}$, espalhou todo o tipo de blasfémias sobre Sócrates e um dos espectadores disse: "Não te irritas, Sócrates, por seres ridicularizado desta forma?"; "Mas com certeza que não, por Zeus!", respondeu, "só porque faço rir no teatro, tal como acontece num grande banquete" ${ }^{101}$.

${ }^{97}$ Plutarco, na Vida de Aristides 4.3, cita o seguinte trímetro jâmbico de um autor desconhecido: "era um homem sábio, mas sem controlo nas mãos".

${ }^{98}$ General enviado por Esparta à Sicília, no ano 415 a. C., contra os Atenienses, durante a Guerra do Peloponeso. Cf. Plutarco, Vida de Lisandro 16-17, Vida de Nícias 28.4 e Vida de Péricles 22.4.

${ }^{99} \mathrm{Cf}$. $O$ controlo da ira 457A.

${ }^{100}$ Em 423 a. C.; vide Platão, Apologia de Sócrates 19c e, ainda, Plutarco, Vida de Demóstenes 15.1.

${ }^{101}$ Cf. Plutarco, No banquete $707 \mathrm{E}$. 
Semelhantes coisas e outras análogas a estas parecem ter feito Arquitas de Tarento e Platáo. Aquele ao regressar da guerra (em que foi general) encontrou a sua terra por cultivar; chamou, entâo, o caseiro e disse: "Lamentarias isto, se eu não estivesse tão agastado" ${ }^{102}$. Platão, por sua vez, irritando-se com um escravo guloso e desavergonhado, chamou o filho da irmã, Espeusipo $^{103}$, e disse enquanto se afastava: "Bate-lhe tu. Eu estou demasiado irritado" ${ }^{104}$. Contudo, alguém poderia dizer que estes actos são penosos e difíceis de imitar. Eu bem o sei. É, no entanto, necessário fazer um esforço por usar estes exemplos tanto quanto seja possível e suprimir uma grande parte da ira descontrolada e agressiva. $\mathrm{Na}$ verdade, nós não somos comparáveis a esses filósofos, nem na experiência, nem na escrupulosa probidade. Porém, tentemos não ser inferiores a eles, como se fôssemos hierofantes dos deuses e intérpretes da sabedoria. Tentemos, pois, na medida do possível, imitá-los e aproveitar o que nos deixaram.

Pois bem, em relação a refrear a língua (sobre este assunto falta-nos, como prometi, falar), se alguém pensar que é pouco importante e que não tem utilidade, anda muito longe da verdade. Com efeito, o silêncio oportuno é sábio e melhor do que qualquer discurso ${ }^{105}$. Por causa disto, parece-me que os antigos instituíram

${ }^{102}$ Cf. Plutarco, As delongas da justiça divina 551B.

103 Sobrinho de Platão que lhe sucedeu na direcção da Academia, entre 347 e 339.

${ }^{104}$ Cf. Séneca, Da ira 12.6 e Plutarco, Contra Colotes 1108A.

${ }^{105}$ Sobre o valor do silêncio na obra de Plutarco, vide C. Fuentes (2005: 191-8); cf. supra Da educação das crianças 5E-F e 10B-F. 
os cultos de natureza mistérica, para que, acostumados ao silêncio neles, transportemos o temor pelos deuses para a confiança nos mistérios humanos. De facto, ninguém se arrependeu de ter ficado calado, mas muitos se arrependeram de haverem tagarelado ${ }^{106}$. É fácil dizer o que se cala, mas não é possível retirar o que se disse. Eu próprio sei que, por terem ouvido, muitos caíram em

I IA grande desgraça, devido aos excessos da língua. Destes, deixando outros de lado, recordarei um ou dois como exemplo. Quando Filadelfo casou com a sua irmá Arsínoe, Sótades ${ }^{107}$ por dizer:

"Espetas o teu aguilhão num buraco não puro",

ficou na prisão por muitos anos e cumpriu uma sentença justa por causa da sua tagarelice inoportuna. É que por fazer rir os outros, chorou ele durante muito tempo.

Coisas comparáveis e análogas a estas também o sofista Teócrito ${ }^{108}$ as disse e as sofreu, e de forma muito mais terrível. Quando Alexandre ordenou que os Helenos se preparassem com vestidos de púrpura, para que no seu regresso se celebrassem com sacrifícios as vitórias

${ }^{106}$ Apesar de aqui não identificar este apotegma, Plutarco, em $A$

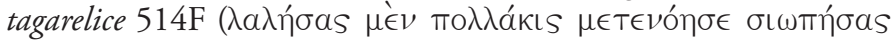

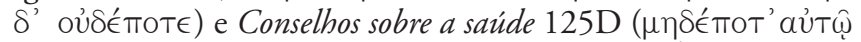

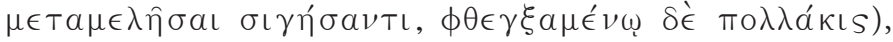
atribui-o a Simónides.

${ }^{107}$ De origem incerta, sabe-se, no entanto, que foi autor de poemas obscenos, no tempo de Ptolomeu II Filadelfo (283-246 a.C.).

${ }^{108}$ Teócrito de Quios (séc. IV-III a.C.), discípulo de Metrodoro e também orador (cf. Plutarco, No banquete 633C-D); sobre esta história, vide FGrH 81 F41. 
da guerra contra os Bárbaros, e como os povos contribuíram, numa determinada quantia por cabeça, com prata, Teócrito disse: "No início tinha dúvidas, mas agora compreendo, claramente, que a morte purpúrea de Homero é isto" ${ }^{109}$. Estas palavras provocaram-lhe a inimizade de Alexandre. Demonstrou igualmente uma ira excessiva para com Antígono ${ }^{110}$, rei dos Macedónios, que era cego, quando salientou a sua deficiência. Então, Antígono, tendo enviado a Teócrito o seu antigo cozinheiro, Eutrópion, que desempenhava um alto cargo, solicitou-lhe que se apresentasse a ele e lhe desse e recebesse explicaçóes. Comunicando-lhe estas coisas e indo ao seu encontro repetidas vezes, Teócrito disse ao cozinheiro: "Bem sei que queres servir-me cru ao Ciclope" Insultou, desta forma, um porque era cego e o outro porque era cozinheiro. Em troca Eutrópion respondeu: "Por causa disso, serás decapitado e serás punido pela tua tagarelice e pela tua loucura”. Transmitiu o que tinha dito ao rei, que mandou chamar Teócrito para ser morto ${ }^{112}$.

A acrescentar a todos estes conselhos, o mais sagrado é habituar as crianças a dizer a verdade. Pois mentir é próprio dos escravos e torna o homem digno de ser odiado por todos e essa prática não é perdoável sequer aos escravos moderados.

15. Eu falei, sem dúvidas ou hesitaçóes, dos assuntos relacionados com a boa conduta e a prudência

${ }^{109}$ Cf. Iliada 5. 82-3, 16.333-4, 20.476-7.

${ }^{110}$ General de Alexandre.

${ }^{111}$ Sobre o conhecido Ciclope homérico, vide Odisseia 1.69 e sqq., 166 e sqq.

${ }^{112}$ Cf. Plutarco, No banquete 633C. 
das crianças. Mas estou indeciso e dividido sobre o que

D vou dizer, inclinado ora para um lado ora para outro, como sobre os pratos de uma balança, não podendo ser favorável a um ou a outro; não sei se hei-de empreender ou omitir esta temática. Devo, no entanto, ter a ousadia de a abordar. De que se trata? ${ }^{113}$ Acaso se deve permitir que pederastas convivam e habitem com as crianças ou, pelo contrário, convém impedi-los e afugentá-los da conversação com elas? Quando observo a severidade dos pais que, com uma atitude austera e amarga, consideram uma insolência insuportável a relação das crianças com aqueles que as amam, eu

E temo ser a favor desta atitude. Quando, contrariamente, penso em Sócrates, Platão e Xenofonte, Ésquines e Cebes ${ }^{14}$ - todo um coro de pessoas que aprovaram o amor entre homens e guiaram os jovens para a educação, para a actividade pública e para atitudes virtuosas - então, passo a ter outra opiniáo e aproximo-me

${ }^{113}$ É desta forma relutante e indecisa que se introduz a temática da pederastia, bem presente na tradicional paideia grega, em especial nos círculos filosóficos; daí as referências no texto a Sócrates (que é mencionado em várias histórias anedóticas com fins didácticos: 4D-E, 6A, 10C-D) ou Platão, uma figura que é, ao longo do tratado, um símbolo de conhecimento e uma autoridade em diversas matérias (3E-F, 4D-E, 6A, 7D, 8C). O autor sente a dificuldade de conciliar a admiração por esses filósofos e as suas práticas com o facto de esse instrumento educativo ser reprovado na sua época. Talvez por isso, o autor deixe, no final desta parte, ao leitor liberdade para fazer os seus próprios julgamentos sobre esta matéria.

${ }_{114}$ Amigos e discípulos de Sócrates, os quatro que o acompanham nesta matéria. Sobre o eros paidikos, cf. Erótico 749C-F, 752B-F e 755B: neste tratado, entre outros assuntos, discutem-se as vantagens e as desvantagens da pederastia e do casamento. 
do zelo deste homens. Da mesma forma, Eurípides ${ }^{115}$ é testemunha deles ao afirmar:

Mas existe entre os mortais um outro amor, de alma justa, prudente e boa.

Não deve ser esquecido o facto de Platão ${ }^{116}$ lhe juntar seriedade e humor. Diz que é preciso que chegue aos que são melhores, se quiserem ser amados pelos belos. Convém, pois, que se exclua o desejo da beleza, mas que se elejam, sempre, os amantes da alma. Deve fugirse dos amores de Tebas, Élide ${ }^{117}$ e Creta ${ }^{118}$, conhecida pelo costume do "rapto", mas louvar o que é praticado em Atenas e na Lacedemónia.

16. Sobre este assunto, cada um tenha as suas próprias conviç̧óes e proceda em conformidade. Eu, depois de ter falado sobre a disciplina e a conduta das crianças, deter-me-ei, de imediato, na juventude, fazendo um brevíssimo preâmbulo. De facto, muitas vezes repreendi os instigadores de costumes perversos, aqueles que entregam os filhos aos pedagogos e mestres, mas permitem que o desejo libertino domine os jovens; em vez disso, é necessário ter mais precaução e atenção com os jovens do que com as crianças. Quem não sabe, de facto, que os erros das crianças são irrelevantes e completamente corrigíveis, como as atitudes de desprezo

${ }^{115}$ Em Teseu, frg. 388.1-2.

${ }^{116}$ República 468b.

${ }^{117}$ Platão, Banquete 182a-185c.

${ }^{118}$ Sobre o harpagmos ou 'rapto' cretense, vide FGrH 70 F149.20 e Estrabão 10.4.21. 
pelos pedagogos e as faltas ou a desobediência para com os seus mestres? No entanto, as ofensas dos jovens são, muitas vezes, grandes e graves: o excesso de comida, o furto de bens familiares, os jogos de sorte, os festins, o excesso de bebida, as aventuras com raparigas e a sedução de mulheres casadas. Por conseguinte, convém refrear e deter, com diligência, os desejos dos jovens; na verdade, a força da idade não poupa os prazeres, é

c rebelde e necessita de freio. Por isso, se os pais não se preocupam, veementemente, com esta idade, concedem sem dar conta liberdade para cometerem injustiças. É, pois, indispensável que os pais conscienciosos, sobretudo durante esta faixa etária, estejam vigilantes e atentos, e moderem os jovens com ensinamentos, reprimendas, pedidos, conselhos, promessas, indicando o exemplo dos que caem na desgraça por causa do fascínio pelos prazeres ou dos que ganham o louvor e a boa reputação graças à firmeza de espírito. Desta forma, são dois os princípios da virtude: acreditar na honra e temer o castigo. Um princípio leva os mais impetuosos aos costumes D mais nobres, o outro leva os temerosos a hesitar perante as acçôes vis.

17. Em geral, convém afastar as crianças da companhia de homens perversos, uma vez que ganham um pouco da sua maldade. Também Pitágoras aconselhou isto por meio de enigmas, que eu, expondo-os, explicarei, pois eles contribuem de forma decisiva para a aquisição da virtude. Exemplos: "Não comer melanuros ${ }^{119 ", ~ i s t o ~ e ́, ~}$

${ }^{119}$ Cf. Aristóteles, História dos animais 591a; o melanuro é um peixe. 
não permanecer junto de homens negros por causa do seu mau carácter; "não passar por cima de uma balança", ou seja, é necessário dar muito valor à justiça e não saltar por cima dela; "não se sentar sobre a quénice" ${ }^{20}$, isto é, foge da ociosidade e pensa como conseguir o alimento necessário; "não estender a mão direita a qualquer um", em vez de dizer que não convém reatar relações com precipitação; "não andar com um anel apertado", pois é necessário levar uma vida livre e não atá-la com nós; "não atiçar o fogo com o ferro" ${ }^{121}$, em vez de não provocar o que está irritado, pois é preferível condescender com os que se irritam; "não comer o coraçáo", ou seja, não prejudicar a alma com preocupaçóes que a consomem; "abster-se das favas" ${ }^{122}$, que não convém dedicarse à política, pois, antes, as votaçóes faziam-se com favas e por meio delas dava-se o fim às magistraturas; "não $\mathrm{F}$ lançar comida no bacio", indica que não se deve dirigir um raciocínio a uma alma perniciosa, pois o raciocínio é o alimento da reflexão e a perversidade dos homens torna-o impuro; "não se voltar ao chegar à meta", isto é, quando se está quase a morrer e se vê o fim da vida próximo, convém aceitá-lo de forma complacente e não desanimar.

Retomarei agora o assunto do início da exposição. É necessário, como afirmei, afastar as crianças dos

${ }^{120}$ Medida de capacidade para produtos secos. Cf. Hesíodo, Trabalhos e Dias 301 e sqq., Tucídides 2. 40.

${ }^{121}$ Nós diríamos antes "não deitar mais lenha para a fogueira". Cf. Questóes Romanas 281A e Ísis e Osíris 354E.

${ }^{122}$ Forma de não participar numa votação; cf. Plutarco, Questóes Gregas 286D e Diógenes Laércio 8.19 e 8.33. 
homens perniciosos e, sobretudo, dos aduladores ${ }^{123}$. Agora gostaria de dizer o que repito a muitos pais: não

I3A existe nenhuma raça mais nociva, nem, o que é pior, mais célere a lançar a juventude na desgraça do que os aduladores, que destroem desde a raiz ${ }^{124}$ os pais e os filhos, afligindo a velhice daqueles e condicionando a juventude destes, propondo como isco dissimulado dos seus conselhos o prazer. Enquanto aos filhos dos ricos os pais aconselham a sobriedade, os aduladores, pelo contrário, aconselham a embriaguez; aqueles a prudência, estes a insolência; aqueles a moderação, estes o esbanjamento; aqueles o amor pelo trabalho, estes a preguiça, dizendo: "Toda a vida é um breve instante ${ }^{125}$, por isso convém viver e não desperdiçar a vida. Porque в nos devemos preocupar com as ameaças do pai? Ele é um velho tolo e um cadáver ambulante, e, carregando-o sobre os ombros, nós enterrá-lo-emos em breve”. Um outro póe-lhes à frente uma meretriz ou prostitui a esposa $^{126}$, e despoja e rouba o património dos pais para a sua velhice. Raça impura, amigos dissimulados, que não gostam da sinceridade, pois adulam os ricos e desprezam os indigentes; dirigem-se aos jovens com a arte lírica, rindo às gargalhadas quando aqueles que os sustentam sorriem; são membros enganosos e ilegítimos

${ }^{123}$ Aos kolakes, dedica Plutarco o tratado Como distinguir o adulador do amigo.

${ }^{124}$ Metáfora que ocorre também em Heródoto 1.16 e Eurípides, Hipólito 684.

${ }^{125}$ Cf. Simónides frg. 143 Page (= 196 Bergk); vide Plutarco, Conselhos a Apolónio 117E, Sexto Empírico, Contra os matemáticos 11.49, Estobeu 4.34.58.

${ }^{126}$ Cf. Plutarco, Erótico 759F. 
da vida, que vivem dependentes da anuência dos ricos; são livres por sorte, mas escravos por desígnio. Quando não são maltratados, então pensam que são ultrajados, porque se entretiveram de forma inútil. De modo que, se aos C pais preocupa a boa educação dos filhos, devem expulsar estes rebentos daninhos e, sobretudo, devem afastar a perversidade dos condiscípulos. Na verdade, também estes são capazes de destruir as naturezas mais indulgentes.

18. Estes conselhos procuram, sem dúvida, o bem e o que é útil. Falarei agora sobre os sentimentos humanos. De acordo com a minha opiniáo, não é digno que os pais sejam, por natureza, completamente severos e intransigentes, mas perdoem, com frequência, os erros da juventude, e lembrem-se, eles próprios, de que também já foram jovens. Tal como os médicos, ao misturarem os fármacos amargos ${ }^{127}$ com substâncias doces, descobriram naquilo que é agradável um caminho para a utilidade, é necessário também que os pais combinem a severidade das repreensóes com a afabilidade, ou seja, que ora soltem e afrouxem as rédeas aos desejos ${ }^{128}$ dos jovens, ora as retenham; tolerem os erros de forma mais complacente, ou senão, após um momento de irritação, acalmem-se rapidamente. De facto, é melhor o pai ser irascível do que rancoroso, porque a raiva e a inflexibilidade são claros sinais de ódio para com os filhos. É bom fingir que não se conhecem alguns dos erros e ter uma vista fraca e ouvidos surdos, como um velho, para

${ }^{127}$ Cf. Ovídio, Arte de Amar 2.335; Plutarco, Conselhos conjugais $141 \mathrm{~F}, A$ tagarelice 509C.

${ }^{128}$ Sobre os desejos dos jovens, vide Plutarco, Como devem os jovens ouvir poesia 37C. 
E com a realidade, de modo a não ver algumas coisas que se vêem e a náo ouvir o que se ouve ${ }^{129}$. Se suportamos os erros dos amigos, que admiração há se suportamos os dos nossos filhos? Muitas vezes também não condenámos o excesso de bebida dos escravos toldados pela embriaguez. Algumas vezes foste avarento com o teu filho, mas sê também generoso; algumas vezes irritaste-te, mas perdoa também; outras vezes enganou-te com a ajuda dos criados, mas contém a tua raiva; umas vezes tirou a parelha do campo; em outras ocasióes chegou com um hálito de ter bebido vinho há pouco tempo... ignora-o! Se cheira a perfume, cala-te. Assim se doma uma juventude rebelde.

19. Os que se deixam vencer pelos prazeres e são indiferentes às advertências devem experimentar o

F matrimónio, pois esse é o vínculo mais prudente para os jovens. Convém dar em casamento aos vossos filhos mulheres que não sejam mais nobres nem muito mais ricas. É sábio quem disse: "Escolhe o teu semelhante" ${ }^{130}$.

I4A Os homens que não tomam a mulher adequada esquecem que se tornam escravos dos dotes.

20. Concluirei estes conselhos, acrescentando, ainda, umas breves palavras. Antes de tudo, torna-se indispensável que os pais não cometam erros com os filhos, mas que façam bem todas as coisas e se revelem exemplos indiscutíveis para eles ${ }^{131}$, a fim de que, ao olha-

${ }^{129}$ Semelhante tom proverbial em Plutarco, Conselhos Politicos 818B.

${ }^{130}$ Vide Calímaco Epigramas 1.12, sentença atribuída a Pítaco (= Antologia Palatina 7.89).

${ }^{131}$ É recorrente ao longo do tratado a ideia de que se devem 
rem para a vida dos pais como um espelho, se afastem de acçóes e palavras ignominiosas. Aqueles que repreendem os erros dos filhos, erros em que eles também caíram, esquecem que se acusam a eles próprios por meio do nome dos filhos. Ou seja, os que levam uma vida sem regras náo se sentem com confiança para repreender os escravos, e muito menos os próprios filhos. Pior ainda, poderiam ser para os filhos conselheiros e mestres dos seus vícios. De facto, naquilo em que os velhos são impudicos, aí é forçoso os jovens também serem despudorados. Por conseguinte, os pais devem esforçar-se por cuidar de tudo quanto é necessário para a instrução dos filhos, procurando imitar Eurídice ${ }^{132}$, que, embora sendo ilíria e três vezes bárbara, se dedicou à instrução em idade avançada para ensinar os seus filhos. Assinala, de forma clara, o seu amor materno num epigrama que consagrou às Musas:

Eurídice, filha de Hirra, consagrou este poema aos

[concidadãos, tomada na sua alma por um desejo de fazer uma oferta às

[Musas.

Sendo mãe de filhos em plena juventude, dedicou-se a aprender as letras, que preservam a memória.

imitar os paradeigmata: 4B, 9A, 10E, 11E, 12A, 12C e 14B.

${ }^{132}$ Geralmente identificada como a esposa de Amintas III da Macedónia (390-369 a. C.) e avó paterna de Alexandre Magno; além de Eurínoe, teve mais três filhos: Alexandre II, Perdicas III e Filipe II; cf. Suda, k. 356 (o nome de Eurínoe não surge referido entre a descendência de Eurídice); vide ainda Ateneu, Banquete dos Sábios 13.10.41 e Polieno, Estratégias 8.60. 
É, sem dúvida, uma acção digna tentar realizar todas as recomendaçóes expostas. Para que a maior parte das pessoas atinja esse objectivo, é certamente necessário muito talento e diligência, mas é algo que está, seguramente, ao alcance da natureza humana. 


\section{BibLIOGRAFIA}

\section{EDIÇÓES, TRADUÇÓES E COMENTÁRIOS}

R. Frasca (1994), Pseudo-Plutarco: Come educare i proprifigli, Firenze.

W. R. Paton, M. Pohlenz, H. Wegehaupt \& H. Gärtner (1993), Plutarchus: Moralia vol. 1, Stutgardiae et Lipsiae.

J. Sirinelli (1987), Plutarque. Oeuvres Morales, Tome I, Paris.

\section{Estudos}

N.J.S. Abbot (1980), The Treatise De liberis educandis attributed to Plutarch, Oxford.

F. Albini (1997), "Family and the Formation of Character. Aspects of Plutarch's Thought”, in Judith Mossman (ed.), Plutarch and his Intellectual World. London, 59-71.

E. Berry (1958), “The De liberis educandis of Ps.-Plutarch", HSCPh 63 388-99.

J. Bruner (1999), Para uma Teoria da Educação, Lisboa.

C. Fuentes (2005), "El oportuno silencio: una norma educativa para Plutarco", in M. Jufresa et al. (Eds.), Plutarc a la seva època: Paideia i societat (Actas dels VIII Simposio Internacional de la Sociedad Española de Plutarquistas, Barcelona, 6-8 
nov. 2003), Barcelona, 191-198.

J. García López (1983), "Educación y crítica literaria en la helenidad tardía: el De Liberis educandis, atribuido a Plutarco", in Unidad y pluralidad en el Mundo Antiguo. Actas del VI Congreso Español de Estudios Clásicos II, Madrid, 83-90.

W. Jaeger ( $\left.{ }^{4} 2001\right)$, Paidéia. A Formação do Homem Grego, São Paulo.

N. Kennel (1995), The Gymnasium of Virtue. Education and Culture in Ancient Sparta, Chapel Hill \& London.

H. Koller (1995), "ENKUKLIOS PAIDEIA”, Glotta 34 174-189.

G. Lachenaud (1997: 65-102), "L'enkyklios paideia et l'esprit encyclopédique dans l'Antiquité", $R P h$ 71.1.

D. F. Leão (2005), "Sólon e a legislação em matéria de direito familiar", Dike n.s. 8 5-31.

H. I. Marrou (1990r), História da Educação na Antiguidade, São Paulo.

H. J. Mette (1960), “ENKUKLIOS PAIDEIA”, Gymnasium 67 300-307.

T. Morgan (2000r), Literate Education in the Hellenistic and Roman Worlds, Cambridge.

J. Pinheiro (2003), "Significado de Paideia no tratado 
pedagógico De liberis educandis", in M. Z. Gonçalves Abreu e M. de Castro (Coords.), Estudos de Tradução - Actas de Congresso Internacional, Cascais, 473-484.

(2007), "De liberis educandis", in de J.A. Fernández Delgado, F. Pordomingo \& A. Stramaglia (Eds.), Escuela y literatura en Grecia Antigua (Actas del Simposio Internacional Universidad de Salamanca, noviembre 2004), Università degli Studi di Cassino, 349-362.

A. E. Velázquez Fernández (1999), "Límites del Influjo Platónico en el ПЕPI ПАI $\Omega N A Г \Omega Г H \Sigma$, in A. Pérez Jiménez, J. García López \& R. Ma Aguilar (Eds.), Plutarco, Platón, Aristóteles, Actas del V Congreso Internacional de la I. P. S. (MadridCuenca, 4-7 de mayo de 1999), Madrid, 501514.

P. Volpe Cacciatore (2000), "Plutarco e Toma Magistro: l'educazione dei figli", Vichiana 4. ser. 2 55-61.

B. Weissenberger (1994), La Lingua di Plutarco di Cheronea e gli Scritti Pseudoplutarchei, a cura di Giovanni Indelli e premessa di Italo Gallo, Napoli.

D. Wyttenbach (1820), Animadversiones in Plutarchi opera moralia, I. Lipsiae. 


\section{Volumes publicados na ColecÇÃo Autores \\ Gregos e Latinos - Série TEXTos}

1. Delfim F. Leão e Maria do Céu Fialho: Plutarco. Vidas Paralelas - Teseu e Rómulo. Tradução do grego, introdução e notas (Coimbra, CECH, 2008).

2. Delfim F. Leão: Plutarco. Obras Morais - O banquete dos Sete Sábios. Tradução do grego, introdução e notas (Coimbra, CECH, 2008).

3. Ana Elias Pinheiro: Xenofonte. Banquete, Apologia de Sócrates. Tradução do grego, introdução e notas (Coimbra, CECH, 2008).

4. Carlos de Jesus, José Luís Brandão, Martinho Soares, Rodolfo Lopes: Plutarco. Obras Morais - No Banquete I - Livros I-IV. Tradução do grego, introdução e notas. Coordenação de José Ribeiro Ferreira (Coimbra, CECH, 2008).

5. Ália Rodrigues, Ana Elias Pinheiro, Ândrea Seiça, Carlos de Jesus, José Ribeiro Ferreira: Plutarco. Obras Morais - No Banquete II - Livros V-IX. Tradução do grego, introdução e notas. Coordenação de José Ribeiro Ferreira (Coimbra, CECH, 2008).

6. Joaquim Pinheiro: Plutarco. Obras Morais - Da Educação das Crianças. Tradução do grego, introdução e notas (Coimbra, CECH, 2008). 
OBRA PUBLICADA

COM A COORDENAÇÁO

CIENTÍFICA

0

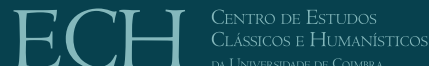

DA UNIVERSTIDAD DE COIMBRA

- $\mathbf{U}$

C •

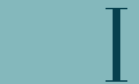

IMPRE VSA DA UNIVERSIDADE DE COINPRA 